\title{
REVIEW OF FACTORS AFFECTING THE RELEASE OF WATER FROM CELLULOSIC FIBERS DURING PAPER MANUFACTURE
}

\author{
Martin A. Hubbe and John A. Heitmann \\ The ease with which water is released from cellulosic fiber material \\ during the manufacturing of paper can affect both the production rate \\ and the consumption of energy during the manufacturing process. \\ Important theoretical contributions to dewatering phenomena have been \\ based on flow through packed beds of uniformly distributed fibers. Such \\ descriptions are able to explain why resistance to dewatering increases \\ as a function of the hydrodynamic surface area of fibers. More recent \\ studies have demonstrated a critical role of finely divided matter. If the \\ fines are unattached to fibers, then they tend to move freely through the \\ fiber mat and plug channels in the paper web during the dewatering \\ process. Dewatering also is affected by the deformability of cellulosic \\ fibers and by whether the fibers easily slide past each other, thereby \\ forming a dense mat. By emphasizing the role of fine matter, colloidal \\ forces, and conformability of cellulosic materials, one can gain a more \\ realistic understanding of strategies that papermakers use to enhance \\ initial drainage and vacuum-induced dewatering.
}

Keywords: Dewatering, Drainage, Freeness, Fines, Water retention value, Kozeny-Carman, Choke-point mechanism, Mobility of fines, Sheet sealing, Sediment volume

Contact information: Department of Forest Biomaterials Science and Engineering, North Carolina State University, Campus Box 8005, Raleigh, NC 27695-8005 USA, hubbe@ncsu.edu, heitmann@ncsu.edu

\section{INTRODUCTION}

The removal of water from cellulosic fibers and other materials in the wet web constitutes the most energy-demanding part of the paper manufacturing process (McGregor and Knight 1996). This review considers various ways in which investigators have sought to explain the dewatering process and to understand factors that can either increase the rate of production or reduce the consumption of energy.

To put things into perspective, one can divide paper dewatering operations into phases. The first phase involves impingement of a low-solids fibrous suspension onto one or between a pair of highly permeable fabrics, which are manufactured as continuous belts. During operation of a modern paper machine, such fabrics can travel at surface speeds up to $1900 \mathrm{~m} / \mathrm{min}$. Because the suspension impinging onto a forming fabric typically has a solids content between 0.3 and $1 \%$, some of the water will require only gravity and inertia to flow out of the cellulosic mixture.

The next phase of the dewatering process often involves a subtle disturbance of the developing web of paper, using devices such as hydrofoils. A hydrofoil is placed on the side of a fabric opposite from where the paper is being formed, and it is designed to apply a very short-term vacuum impulse. In addition to doctoring some water from the 
back of the fabric, hydrofoils tend to jostle the wet web, freeing up drainage channels, and also tending to make the paper somewhat more uniform within the plane of the sheet.

A third phase of the dewatering process involves systematic application of vacuum, usually by means of vacuum flat-boxes and a perforated roll (the "couch" roll), over which the fabric travels. After passing over the couch roll, the paper web solids content is usually in the range $18-25 \%$. Then it passes through a series of press nips, where water is forced from the sheet into the void spaces of continuous felts. After pressing, the paper web solids content usually is in the range of about $40-55 \%$. The final operation in removing water from paper usually occurs as the sheet travels in serpentine fashion over a series of steam-heated rolls. The finished paper should have a moisture content of about $4-8 \%$, roughly corresponding to the equilibrium moisture content of the paper under the humidity conditions at which it will be used.

According to McGregor and Knight (1996) the cost to remove one unit of moisture in the forming, pressing, and drying sections of a paper machine is related by the ratios 1:5:220. It is often possible to save energy by slowing down a paper machine, thus increasing the effectiveness of dewatering in the forming and pressing operations (Mansfield 1986). Because of the high capital costs of papermaking equipment, as well as the energy costs associated with papermaking, papermakers are motivated to find ways to produce more tons of product at a constant input of time and energy.

As noted in recent reviews, a variety of test methods have been developed to predict how rapidly water will be released during the production of paper (Kerekes and Harvey 1980; Roschy et al. 2002; Hubbe 2003). Briefly stated, these methods involve various standard conditions of filtration (Kerekes and Harvey 1980; Pires et al. 1989; Anon. 1994a), sometimes with automatic recording of the filtrate mass versus time (Sampson 1997; Bley and Falkenberg 2001), sometimes with application of vacuum (Gess 1984; Pires et al. 1989, Wang and Hubbe 2001; Roschy et al. 2002), or with pressure pulsations intended to simulate the environment of a modern paper machine (Persson and Österberg 1969; Britt et al. 1986; Lin and Schuster 1992; Räisänen et al. 1995; Sutman 2000). Some recent progress has employed computerized addition of papermaking chemicals, increasing the precision with which it is possible to evaluate different chemical strategies to promote more rapid release of water (Bley and Falkenberg 2001; Roschy et al. 2002). Even the traditional Canadian Standard Freeness test (Anon. 1994a) recently has been automated and improved in order to extract additional information that might be correlated to on-machine dewatering performance (Corscadden 2005).

Further progress has been achieved by measuring the water-retaining ability and particle size of cellulosic fines in a suspension; this approach was found to give a high correlation with the dewatering characteristics of combined furnish from which the fines were obtained (Kang and Paulapuro 2006). Because the fines fraction of papermaking furnish appears to play such a predominant role relative to dewatering rates, it should be emphasized that a wide variety of very small solid materials are apt to be present in papermaking stock. Cellulosic fines may consist of ray parenchyma cells (primary fines) or of fibril fragments removed from cell walls during refining (secondary fines). Mineral particles used as "fillers" in paper products are also counted as "fines" by many authors. Colloidal matter, including emulsion droplets, polyelectrolytes, and polyelectrolyte 
complexes also can be considered as fines, depending on the scope of an investigation. When considering the mechanisms to be described in the following sections, it is quite likely that different types of fines behave differently.

\section{PACKED BED CONCEPTS}

\section{Specific Surface Area}

Kozeny (1927) showed that the resistance to flow through packed beds of granular materials could be explained in terms of the size and number of pores. His ideas were extended by Carman $(1938,1939)$, who verified the equation and introduced such concepts as hydrodynamic radius, specific surface area, and the effects of tortuosity. A commonly cited form of the Kozeny-Carman equation is given in Eq. (1),

$$
k=(\gamma / \mu)\left(2 / C_{\mathrm{K}-\mathrm{C}}\right)\left(1 / S_{\mathrm{o}}^{2}\right)\left[e^{3} /(1+e)\right]
$$

where $k$ is the permeability (length/time), $\gamma$ is the unit mass of the fluid, $\mu$ is the fluid's dynamic viscosity, $C_{\mathrm{K}-\mathrm{C}}$ is the Kozeny-Carman coefficient (usually taken to be about 5), $S_{\mathrm{o}}$ is the specific surface area per unit displacement volume of particulate material, and $e$ is the fractional void volume (Carrier 2002; Chapuis and Aubertin 2003). The permeability coefficient is defined in reference to d'Arcy's law,

$$
\mathrm{d} V / \mathrm{d} t=k A \Delta P_{\mathrm{f}} /(\mu L)
$$

where $V$ is the filtrate volume at time $t, A$ is the cross-sectional area available for flow (disregarding the presence of a solid phase), $\Delta P_{\mathrm{f}}$ is the pressure drop across the permeable material, $\mu$ is the viscosity, and $L$ is the linear length of the column through which the fluid passed through the permeable material. In cases where all of the other parameters can be determined, equations (1) and (2) sometimes are employed to estimate the specific surface area of material in a packed bed (Sullivan and Hertel 1942).

Ingmanson $(1952,1953)$ showed that the same concepts could be applied to compressible materials, such as cellulose. The situation considered was constant pressure dewatering through a fiber pad of uniform composition. The following equation was proposed to represent the average specific resistance, defined on a mass basis,

$$
R_{\mathrm{w}}=k S_{\mathrm{w}}^{2} \Delta P_{\mathrm{f}} /\left\{\int_{0}^{\mathrm{p}}\left[(1-a c)^{3} / c\right] \mathrm{d} p\right\}
$$

where $S_{\mathrm{w}}$ is the specific surface area of the fibers, $a$ is the effective specific volume of the fibers, $c$ is the mass of fibers in a uniform bed, and $p$ is the compacting pressure.

Over the years, various researchers have built upon the work of Kozeny, Carman, and Ingmanson, verifying and fine-tuning the theory (Whitney et al. 1955; Tiller and Cooper 1960; Meyer 1962; Nelson 1964; Tiller and Shirato 1964; Han 1969; Kyan et al. 1970; Binotto and Nicholls 1979; Jackson and James 1986; Jonsson and Jonsson 1992a,b; Nordén and Kauppinen 1994; Mantar et al. 1995; Kumar et al. 1996; Ramarao and Kumar 1996). Whitney et al. (1955) and Jackson and James (1986) compared particulate 
materials having a wide range of shapes; they found that all of the results tended to fall on the same line of flow resistance as a function of the square of the characteristic radius and the volumetric content of solid matter. Such results provide strong support for the general concept. Chan et al. (1996) showed that the Kozeny-Carman equations agreed well with experimental results involving mixtures of differently shaped particles, all having roughly the same specific surface area.

The Kozeny-Carman concept also can be adapted to specific situations. For instance, Han (1969) introduced concepts of viscoelastic creep, resulting in progressive densification of fiber mats exposed to constant pressure. Binotto and Nicholls (1979) showed that Kozeny-Carman concepts can be applied with good agreement to different fractions of classified pulp suspensions differing in fiber length and wall thickness. Ramarao and coworkers (Kumar et al. 1996; Ramarao and Kumar 1996) provided an analysis of gravity-assisted dewatering, making it possible to obtain specific filtration resistance data from conventional freeness test equipment. Their model predicts that the density of the fiber pad, especially the part near to the filter screen, will go through a maximum when a fiber suspension is dewatered by gravity. Zhu et al. (1995) showed that related concepts originally developed to predict flow through textile materials also can be applied with good accuracy in the case of flow through papermaking fiber mats.

\section{Effects of Fine, High-Surface-Area Suspended Matter}

One of the hoped-for benefits of using calculations based on the Kozeny-Carman approach has been to account for effects of fine suspended matter having a relatively high surface area per unit mass, or "specific surface area." Consistent with theory, it has been found that fine mater having the smallest size and highest specific surface area tends to have the greatest adverse effect on dewatering (Przybysz and Szwarcsztajn 1973; Patel et al 1994; Liu et al. 2001). Fibrillar material, mainly composed of delaminated cell wall material, tends to cause greater reductions in dewatering rates, compared to fines having rounded or brick-like shapes, as in the case of parenchyma cells from the wood (Brecht and Klemm 1953; Steenberg et al. 1960; Waterhouse and Omori 1993; Krogerus et al. 2002; Hubbe 2002). Because fine fibrils tend to have a higher surface area per unit mass than blocky or rounded particles, such findings are consistent with the idea that specific surface area has a dominant effect on permeability.

The main effects predicted in the Kozeny-Carman equation are illustrated pictorially in Fig. 1. Consistent with the work of Marton (1980), it will be assumed that the fine matter has a much higher surface area per unit mass, compared to typical fibers in the suspension. As illustrated at right in the figure, a greater frictional resistance is expected when fluid flows through the bed of fines. Although Fig. 1 appears to imply a uniform packing of solid matter, we already have seen that not all users of the Kozeny-Carman equation have made such an assumption (e.g. Ingmanson 1952, 1953).

To apply the Kozeny-Carman equation to suspensions containing odd-shaped finely-divided matter, information about surface area is required. However, surface area within fiber lumens, within the cell wall, and within adsorbed macromolecular material at solid surfaces is not expected to affect the release of water during a conventional gravitybased or pressure-based dewatering experiment. Hence, researchers have sought various ways to assess the "hydrodynamic specific surface area" of suspended matter.

Hubbe and Heitmann (2007). "Water release, papermaking," BioResources 2(3), 500-533. 503 


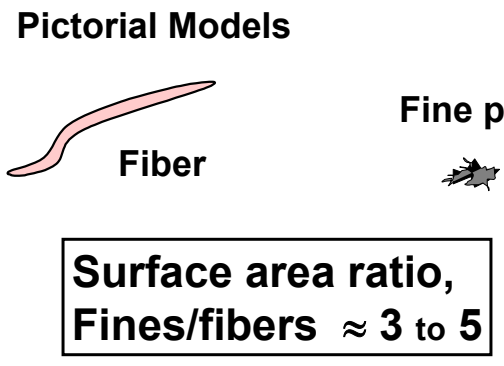

See Marton, Tappi 63 (2), 121 (1980).

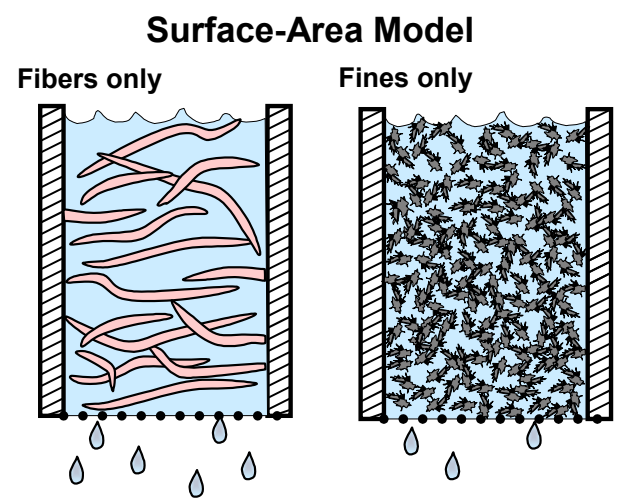

Figure 1. Left: Cartoon representations of typical fiber and typical fiber fine particle in a papermaking pulp suspension. Right: Illustration showing more rapid dewatering through a bed of coarse fibers, in comparison with fine matter, assuming uniform packing density.

Mason (1950) described how the effective hydrodynamic surface area can be estimated by either (a) determining the amount of silver needed to coat the accessible surface of suspended matter, (b) determining the efficiency of light scattering, which often is approximately related to surface area, or (c) by determining the specific resistance to filtration. In fact, Robertson and Mason (1949) were among the first to apply the concepts of Kozeny and Carman to papermaking applications. Marton and Robie (1969), as well as Wood et al. (1991) showed that related information can be obtained very conveniently by evaluating the rate at which fine particles settle out of an unstirred aqueous suspension. Wood and Karnis (1996) extended one of Mason's ideas, showing that turbidity test results, which are related to light scattering, can be used to estimate the hydrodynamic specific surface area of fiber fines. Kang and Paulapuro (2006) described use of a dynamic, centrifugal method to rapidly evaluate the rate of fine-particle sedimentation, and they also demonstrated how one can measure the viscosity of fractionated suspensions of fine matter as a means of estimating the degree to which such matter has become swollen with water.

\section{Effects of Enzymes on Surface Area}

An elegant way to demonstrate the effect of specific surface area on dewatering resistance of cellulosic material is to use enzymes. Cellulase treatments can be optimized to systematically clean up or "polish" the surfaces of fibers and fiber fines, removing fibrillar material that may be projecting outwards from such surfaces. Such a mechanism can explain why cellulase treatment after refining of kraft fibers can provide a substantial increase in drainage rates (Jackson et al. 1996; Eriksson et al. 1997a,b; Gruber and Gelbrich 1997; Seo et al. 2000; Gong et al. 2003; Gong and Bi 2005).

\section{Effects of Wet Fiber Stiffness}

Because the stiffness of fibers, when wet, can affect packing density, one would expect this parameter to affect rates of dewatering. Kayan et al. (1970) incorporated fiber bending into their model to predict filtration resistance. Lindsay and Brady (1993b) found that fibers that had been dried tended to promote more rapid dewatering, consistent with the expected somewhat irreversible effects of drying (Stone and Scallan 1966; 
Klungness and Caulfield 1982; Lindström and Carlsson 1982; Nazhad and Paszner 1994; Weise et al. 1996; Maloney et al. 1998; Zhang et al. 2004). Britt (1981) also found that rapid drainage is favored by the presence of relatively stiff fibers. Paavilainen (1993) was able to quantify such concepts, using a new technique for measurements of wet-fiber flexibility.

\section{Mixtures of Particles of Different Size}

Higher packing densities can be expected in the case of suspensions that have wider distributions of particle size (Dodds 1980; Ethier 1991; Andrade et al. 1992). In effect, smaller particles can fill in spaces that would necessarily occur within suspensions consisting only of larger particles. Consistent with this effect, resistance to dewatering has been found to be larger, in the case of mixtures, than could be explained in terms of a linear combination of results from dewatering tests with uniform suspensions (Abe et al. 1979; MacDonald et al. 1991).

\section{Deviations from Kozeny-Carman Predictions}

Studies showing significant deviations from predictions based on the KozenyCarman concept provide evidence that other mechanisms may play significant roles in controlling rates of water release from cellulosic material. For example, Hawes and Doshi (1986) found that the origin of fiber fines, including whether or not they had been recycled, played a large role relative to dewatering rates, to a much greater extent than could be explained by differences in surface area. They proposed that the observed differences were due to differences in flexibility and conformability among the different kinds of fiber fines. As noted by Ingmanson and Andrews (1959) the classical concepts of Kozeny and Carman, even when modified to account for compressibility effects, cannot be expected to adequately deal with effects of "debris" that can contaminate an otherwise uniform porous mat.

One reasonable approach, to account for deviations from classical KozenyCarman concepts, would involve known differences in composition of fiber mats, as a function of distance in the direction of flow. Heath and Hofreiter (1978) provided an excellent demonstration of how simple filtration of a fiber suspension, using conventional handsheet forming equipment, can give rise to Z-directional differences in the proportions of fine materials. Under conditions of very slow, one-directional dewatering, as in the case of a Fourdrinier paper machine making a very heavy-weight product, it is possible to detect effects of more rapid gravity sedimentation of the larger fibers, leaving a higher proportion of fiber fines in the upper part of the sheet (Unbehend et al. 1989). Ramarao et al. (1994) showed that the proportion of fine matter in different layers of a mat formed by filtration can be predicted by the relative ages of different layers, during the forming process. Results were consistent with concepts proposed earlier by Parker (1972), noting that layers of fibers closer to a forming fabric have a higher probability of capturing mobilized fine matter. However, much more uniform composition in the $\mathrm{Z}$ direction can be achieved if the suspension is treated with a retention aid, which apparently binds fine matter to the surfaces of fibers (Tanaka et al. 1982; Ramarao et al. 1994). Mantar et al. (1995) found that dewatering results can be strongly affected by the initial solids content of fibrous suspensions. They proposed that the effects were due to 
(a) increasing association between fine matter and fibers with increasing consistency, and (b) increasing tendency for fibers to entangle, forming flocs, with increasing consistency beyond a certain point (see Hubbe 2007). The distribution of fine matter in machinemade paper also is affected by the washing action of dewatering devices, such as hydrofoils and dewatering blades (Parker 1972; Zeilinger and Klein 1995).

\section{THE CHOKE-POINT HYPOTHESIS}

\section{Fines and Dewatering}

To understand the mechanisms grouped under the heading "Choke Point Hypothesis," one needs to consider the behavior of unattached fine matter in a fiber suspension, and what can happen to such fines as water is being removed. Excellent articles have been written regarding the characteristics of cellulosic materials in fiber suspensions that are small enough, individually, to pass through a conventional forming fabric of a paper machine (Brecht and Klemm 1953; Steenberg et al. 1960; Kibblewhite 1975; Htun and de Ruvo 1978; Marton 1980; Lindholm 1983; Allen 1985; Scott 1986; Gruber et al. 1997; Moss and Retulainen 1998; Luukko and Paulapuro 1999; Blechschmidt et al. 2000; Pruden 2005). Some commonly noted features of the fiber fines fraction, in addition to their small size, include a relatively high ratio of surface area to mass and a tendency to increase the resistance to dewatering. The fines fraction of a papermaking furnish usually is determined by fractionation with a standard screen (Allen 1985; Anon. 1994, 1995; Luukko and Paulapuro 1999; Pruden 2005). In terms of size, one can make an argument that small, entrained air bubbles, which likewise can increase drainage resistance (Brecht and Kirchner 1959; Gertjejansen and Hossfeld 1967; Karras and Springer 1989; Rauch and Sangl 2000; Helle and Paulapuro 2004; Martorana and Kleemann 2006), ought to be considered as part of the fines component of a papermaking furnish.

The choke-point hypothesis is illustrated in Fig. 2. Several writers have proposed that unattached fiber fines, which can move freely through the paper web during the
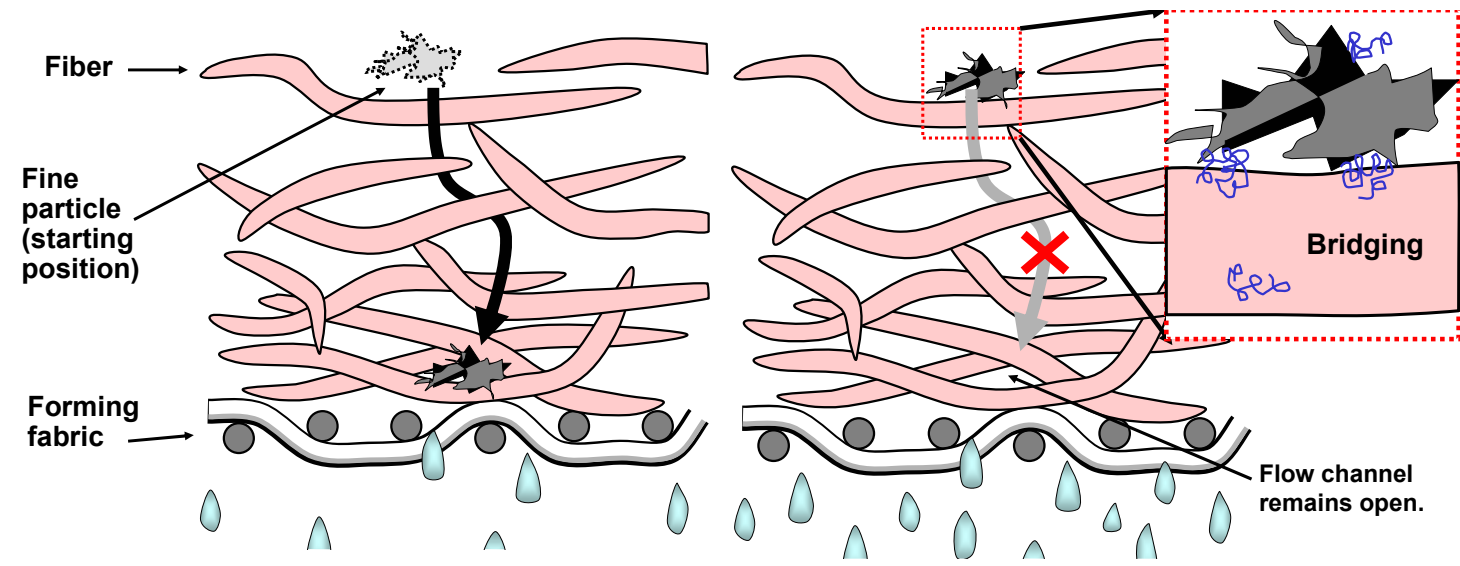

Fig. 2. Left: Schematic illustration of "choke-point" mechanism in which unattached fine particles move through drainage channels to vulnerable points at which they block the flow; Right: Proposed effect of bridging polyelectrolytes on defeating choke-point mechanism by keeping fiber fines attached to fiber surfaces. 
process of dewatering, have a high likelihood of blocking channels through which the water is able to flow (Britt et al. 1986; Patel and Trivedi 1994; Kumar et al. 1996; Räisänen 1996; Wildfong et al. 2000,2003; Paradis et al. 2002; Hubbe 2002). This can be thought of as a manifestation of Murphy's law, since the movement of water through the wet web is expected to transport the fine particles until they get stuck at "choke points," i.e. locations in the mat that happen to be particularly unfortunate with respect to dewatering efficiency. A version of the choke-point hypothesis was enunciated as early as 1969, when Han (1969) proposed that particulate matter in the water could accumulate in a fiber mat, slowing the dewatering rate. A detailed microcopic study by de Silveira et al. (1996) revealed that fines can play a wide variety of roles in a paper sheet, some of which appear to be consistent with the mechanisms just described.

\section{Support for the Choke-Point Mechanism: Fines Level and Basis Weight}

If one begins by assuming that dewatering rates are predominantly controlled by the movement of fines to points where they tend to occlude dewatering channels, then it can be argued that the effect of fines on drainage ought to be nonlinear in character. For sake of discussion, let's envision a very simple mat of fibers in which there happen to be 100 identifiable passages for the flow of water. The first fine particle is drawn by the flow of departing filtrate into a position where it almost completely seals off flow through one of these channels, changing the overall filtration resistance by about $1 \%$. The $50^{\text {th }}$ of the fines blocks the $50^{\text {th }}$ passage, changing the filtration resistance by about $2 \%$. And the $99^{\text {th }}$ fine particle seals off the next-to-last channel, changing the overall filtration resistance by a factor of two! Although this simple arithmetic is not meant to represent a realistic description of pores in a wet-web of paper, nor the efficiency with which a fiber fine would be likely to close off a passage through a wet web, the mechanism implies that resistance to dewatering ought to increase out of proportion to the content of fines, especially when the level of unattached fine begins to approach some critical level. Data generally agreeing with the expectations just cited have been reported in several studies (Molina et al. 1984; Springer and Pires 1988; Hubbe 2002).

A related qualitative analysis can be applied to the subject of basis weight. As noted earlier in this article, fine particles have the highest probability of ending up in a layer of the paper that becomes relatively dense early in the dewatering process. At the limit of a pure filtration mechanism of dewatering (see later discussion), that layer is expected to be near to the filter screen. If the basis weight of the sheet were to be doubled, then the flow of fines-containing water that passes through that layer also will be approximately doubled. As discussed already in the preceding paragraph, each successive fine particle approaching a given layer within the mat of fibers is expected to have a progressively greater adverse impact on dewatering, so the net result is that one expects dewatering resistance to increase out of proportion with increases in basis weight. Again, experimental data from simple filtration analyses tends to support the choke point mechanism in this regard (Gess 1991; Paradis et al. 2002; Wildfong et al. 2000a,b,2003). Though the choke-point model may not be the only way to explain an increase in dewatering resistance out of proportion to basis weight (see, for instance, the "sealing" mechanism, as described later), it is worth noting that Gess (1991) observed a large, 
nonlinear increase in dewatering resistance with basis weight only in a case where the level of fiber fines had been artificially increased, compared to a default condition.

\section{Mobility of Fines}

Further evidence of the action of a choke-point mechanism can be obtained by controlling whether or not fine matter is free to move, relative to its initial position vis-àvis fibers. Issues related to whether or not fiber fines and other solids within a sheet of paper are free to move, relative to a surrounding network of fibers, have been described by Parker (1972). Britt (1981) concluded, based on experiments with controlled agitation of fiber suspensions, that a majority of fiber fines would remain unattached to fibers under typical papermaking conditions. Van de Ven (1984) concluded, however, that it is relatively unlikely for very small particles to become deposited onto fibers during sheet formation, due to hydrodynamic effects. In layman's terms, the water surrounding a fiber tends to act like a lubricant, preventing close approach of small particles as they are carried past the fiber in streamlines of flow. It follows, logically, that most of the collisions, resulting in sticking of fine matter to fiber surfaces must occur earlier in the process. Another view is that electrostatic attraction forces may be able to overcome hydrodynamic forces and bring about "sticking collisions" in such cases.

The concept that fines sometimes can move freely within a paper web during dewatering is supported by studies related to a "healing" mechanism, which appears to be responsible for moderate improvements in formation uniformity (Norman et al. 1995; Sampson 1997). The idea is based on the fact that the initial fibers or fiber flocs impinging onto a forming fabric will have a nonuniform distribution. However, flow toward the forming fabric will become suppressed in those areas already covered. In this way, later-arriving fibers and fines, initially in the upper portion of a jet of slurry landing on a Fourdrinier fabric, will tend to be steered away from high-basis-weight locations and towards voids or thinner parts of the wet web. Further evidence of the relative movement of fines in the thickness direction of paper, during its formation, is shown by non-uniform distributions of fine matter, especially in the case of paper made on Fourdrinier machines, where drainage occurs in one direction (Parker 1972; Tanaka et al. 1982).

At low to moderate levels of hydrodynamic shear the simplest way to prevent fine matter from migrating through the mat of fibers is to employ a very-high-mass acrylamide copolymer, an additive that papermakers refer to as a retention aid (Horn and Linhart 1991; Doiron 1998). Many studies have reported positive effects of retention aid addition on dewatering rates (Britt and Unbehend 1980; Lindholm 1980; Wegner 1987; Karras and Springer 1989). Such results might be explained by noting that the minimum shear stress needed to detach a particle from a fiber surface exposed to flow is a strong inverse function of particle size (Hubbe 1985). The shear stress level that is just sufficient to detach a pair of fibers from each other, overcoming any polymer bridging resulting from the retention aid use, will not ordinarily be sufficient to cause detachment of a smaller particle (Britt 1981; Hubbe 1984; Hubbe and Wang 2002; Huber et al. 2004; Rojas and Hubbe 2004). Thus it is to be expected that a significant proportion of the fines fraction, following treatment of the system with an effective retention aid, will be prevented from participating in a choke-point mechanism. Retention aids can be expected to be especially effective in binding the smallest categories of fines to fiber surfaces,

Hubbe and Heitmann (2007). "Water release, papermaking," BioResources 2(3), 500-533. 508 
and such fines have been implicated in the most severe effects on dewatering (Liu et al. 2001). Small, unattached fines that are compact in character, e.g. filler particles, may have a high probability of passing through the rest of the fiber mat without becoming trapped by a filtration mechanism.

In an effort to evaluate various alternative interpretations, Hubbe (2002) carried out preliminary experiments in which a cationic acrylamide-type retention aid was added alternatively (a) just to the fines fraction, (b) just to the long-fiber fraction, or (c) to the combined furnish. These three situations are illustrated in Fig. 3, which also shows an example of how addition of the flocculant chemical to a suspension of primary hardwood fines caused the fines to become agglomerated. In each case, the fibers and fines were recombined before making a test sheet. Experiments were repeated for two kinds of cellulosic fines. The first set, primary fines, was obtained by fractionating unrefined hardwood pulp. The second set, secondary fines, was obtained by extensive refining of fines-free hardwood fibers. Parallel observations by light microscopy showed that treatments of type (a) caused agglomeration of fines, decreasing their hydrodynamic surface area. In addition, all of the treatments greatly increased the efficiency of retention during the sheet-forming process.

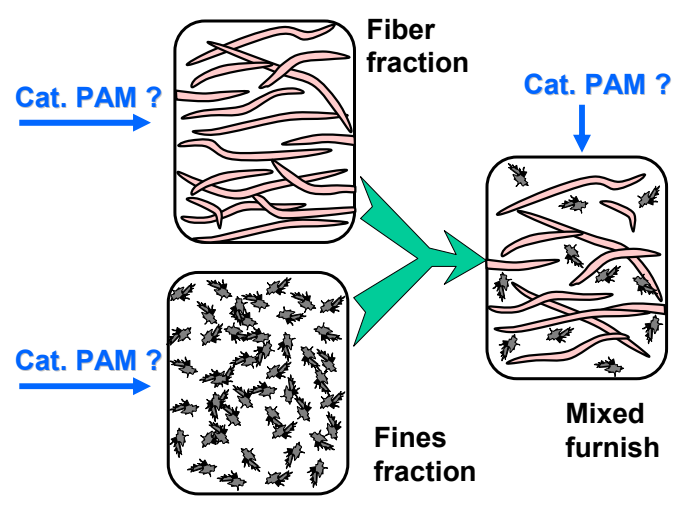

Flocced Primary Fines (200X)

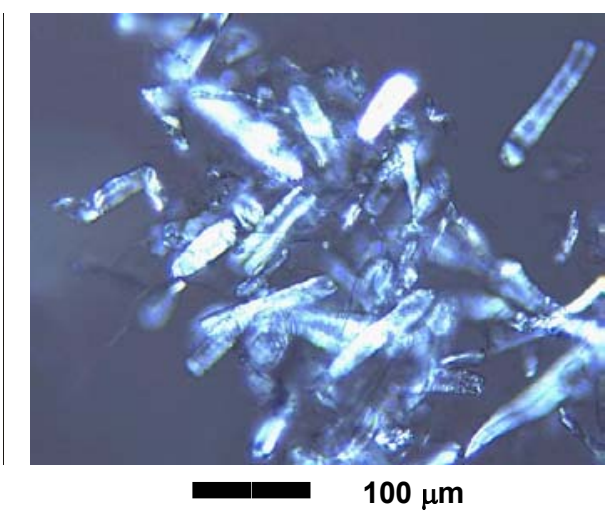

Figure 3. Summary of experimental procedure for treatment of fractionated hardwood kraft furnish either before or after recombining the fines and long fibers and noting the rate of dewatering during formation of paper. A: Treatment options. B: Agglomerated primary fines.

As shown in Fig. 4, each treatment scheme significantly increased the dewatering rates. Particularly large dewatering increases were obtained in cases (a) and (c), roughly corresponding to agglomeration of fines and attachment of fines onto long fibers. Both results are consistent with the choke-point mechanism. Related evidence can be found in studies relating the efficiency of retention to the surface charge and zeta potential of materials in fiber suspensions. Often such studies have shown maximum dewatering rates and maximum retention when aqueous conditions have been adjusted in such a way that the net electrical potential associated with the surface is near to zero (Horn and Melzer 1975; Bhardwaj et al. 2005; Hubbe et al. 2007a). Furthermore, it is well known that high-charge polyelectrolytes and multivalent ions having a charge opposite to that of 
fiber suspensions tend to be effective dewatering aids (Britt and Unbehend 1985; Jaycock and Swales 1994; Maunier and Ramarao 1996; Gruber et al. 1997).
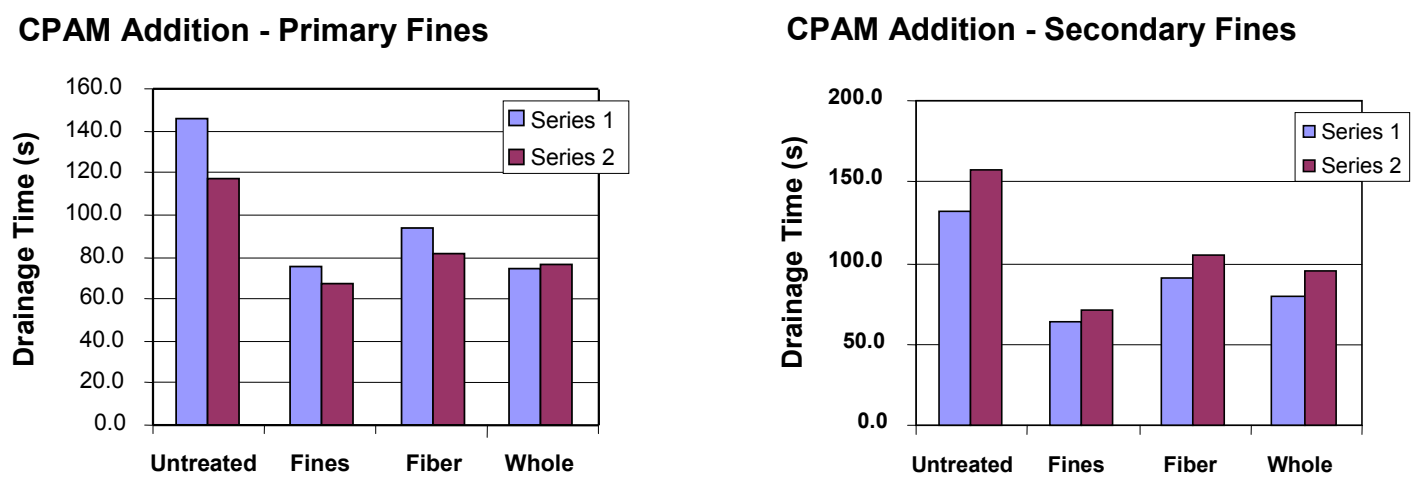

Figure 4. Experimental results for drainage time determinations with untreated bleached kraft furnish with three optional addition procedures of cationic flocculant, (a) addition to the fine fraction only; addition to the long fiber fraction only; and (c) addition to the recombined whole pulp. A: Primary hardwood fines. B: Hardwood fines resulting from refining action.

Liimatainen et al. (2006) found that scalenohdral precipitated calcium carbonate (PCC) of a type having a positive surface charge tended to promote dewatering, in contrast to other kinds of fillers that they tested. They attributed the anomalous results partly to colloidal attraction and efficient retention of the mineral onto the negatively charged surfaces of cellulosic materials. Curiously, this study was almost a mirror image of work reported by Solberg and Wågberg (2002). The latter researchers studied the retention efficiency when negatively charged ground calcium carbonate (GCC) particles were added to suspensions of positively charged fibers. In both cases attraction between surfaces of opposite charge promoted retention of filler particles on fiber surfaces.

\section{Cases in Which Polymeric Treatments Increase Resistance to Dewatering}

In some cases the addition of polyelectrolytes, e.g. carboxylmethylcellulose, has been found to increase the resistance to dewatering. Though such observations may at first appear contrary to the concepts mentioned in the previous subsection, on closer inspection some of the observations can provide further support of the choke-point mechanism. Dunham et al. (2002) observed cases in which the addition of a high-charge cationic polymer to a papermaking furnish having a high cationic demand caused a significant reduction in the rate of dewatering. It was observed that addition of the cationic polymer resulted in the formation of polyelectrolyte complexes, which remained suspended in the white water phase. This mechanism increased the particle size of colloidal material, i.e. "nano-fines," in the white water phase from $1 \mu \mathrm{m}$ to about $20 \mu \mathrm{m}$, which apparently allowed the material to behave similar to fines and choke drainage channels. Interpretation of such results needs to be done with care, however, since polyelectrolyte complexes may promote more rapid dewatering in other cases.

High-mass anionic retention aid polymers often have a negative effect on dewatering (Abson et al. 1980; Gess 1993; Miyanishi and Shigeru 1997; Lee and Lindström 1989), and it can be unclear whether or not such effects are related to a chokepoint mechanism. Abson et al. (1980) reported related effects in the case of an anionic 
retention aid, which was added to a system having aluminum sulfate present; one way to explain such results is to suppose that the alum formed a complex with the polyelectrolyte (Onabe et al. 1983). By becoming coagulated together with other such complexes, the colloidal material might become large enough to behave as small particles and block flow channels in the wet web of paper. Similar observations were reported by Polverari et al. (2001) and Pruszynski and Jakubowski (2002) in the case of high-charge cationic polymer addition to mechanical pulp furnishes, which tend to be rich in anionic colloidal material.

Related results have been reported in the case of a non-ionic retention system based on polyethyleneoxide (PEO) (Cadotte et al. 2005), except that it is not clear from the study whether or not the PEO was present in the form of complexes, or simply adsorbed onto the cellulosic surfaces. Similar effects sometimes can be observed with cationic acrylamide-type flocculants, but apparently only in cases where the system is overdosed with cationic material (Liu et al. 1986). When relatively large amounts of high-mass PEO or acrylamide copolymers are used to disperse long fibers, as in the production of wet-laid nonwoven fabrics, the same additives may be called "formation aids," and the negative effects on dewatering rates can be very substantial (Lee and Lindström 1989).

\section{Time Effects that Support the Choke-Point Mechanism}

The beneficial effect of drainage aids often has been found to pass through a maximum, several seconds after addition of the chemical to an agitated fiber suspension, and then to gradually decay with the further passage of time (Forsberg and Bengtsson 1990; Forsberg and Ström 1994; Hubbe and Wang 2002). Such observations can be explained in terms of an initial deposition of fine solids onto fiber surfaces, followed by gradual re-entrainment into the white water phase. It makes sense that the added cationic polyelectrolytes should initially form bridge-like or patch-like connections (La Mer and Healy 1963; Gregory 1976) between the fine matter and the fibers. However, the passage of time and the influence of hydrodynamic shear can shorten the molecular chains (Sikora and Stratton 1981; Tanaka et al. 1993; Forsberg and Ström 1994) and allow the polymeric additives to lie down flat on the fiber surfaces (Swerin and Ödberg 1997), or to become buried beneath a layer of fibrillation (Hubbe 2006).

Support for a mechanism involving conformational change and/or progressive migration of cationic polymers into pore spaces below fibrils at the fiber surface is provided by a study involving parallel measurements of dewatering and zeta potential (Ström and Kunnas 1991). Greater efficiency, in terms of dewatering, was observed in the case of higher-mass cationic polymers, which appeared to stay on the outer surfaces of suspended matter for a longer time. Based on such observations it makes sense to add dewatering aids relatively late in the approach system to a paper machine forming section, maximizing the degree to which fine particles are being held onto fiber surfaces during the forming process.

\section{Water Retention Values (WRVs)}

Published evidence does not support that idea that high-charge polymeric additives have a large effect on the water that is held within the walls of cellulosic fibers. 
Such a "de-swelling" action is among the possible mechanisms that might be used to explain the action of high-charge cationic dewatering aids (Auhorn 1982; Allen and Yaraskavitch 1991). Procedures involving centrifugation of damp plugs of fiber, allowing the filtrate to pass through a filter and into absorbent material, have been used for many years to estimate the amount of water that is contained within fiber cell walls (Thode et al. 1960; Jayme and Büttel 1968; Ahrens et al. 1999; Anon 1981, 2000). However, if drainage aids mainly functioned by penetrating within the cell walls of fibers, then one would expect their effectiveness to increase with decreasing molecular mass. In fact, the opposite is true (Ström and Kunnas 1991). Highly charged cationic polymers having relatively high mass were found to be much more effective at promoting dewatering, and they also had a much bigger effect in decreasing water retention values, as measured by the centrifugation. It was concluded that the WRV effects were mainly associated with water hold on the outsides of fibers, within layers of fibrillation. The most effective dewatering aids were those having capability to form large positive patches of charge, causing agglomeration of the fibrils. A related study showed that cationic polymers had relatively little effect on water retention values (Maunier and Ramarao 1996), but caused big increases in dewatering rates.

\section{Pulse Dewatering as a Demonstration of the Choke-Point Mechanism}

A key piece of evidence can segue to the next topic. Dewatering tests involving controlled levels of flow or vacuum pulsations often show greatly accelerated rates of dewatering, and much less sensitivity to the presence of fines (Britt et al. 1986; Räisänen 1996; Räisänen et al. 1996; Mitchell and Johnston 2000; Rojas and Hubbe 2004). At least part of the dewatering enhancement effect probably can be attributed to the washing of fine material from the wire-side(s) of the wet web of paper (Egelhof and Bubik 1994; Zeilinger and Klein 1995; Räisänen et al. 1995; Räisänen 1996; Hubbe et al. 2006a), thereby defeating the choke-point mechanism.

\section{SEALING AS A MECHANISM OF DEWATERING RESISTANCE}

Even in cases where fines do not move freely within a fiber suspension, there is another mechanism that can inhibit flow through the densest layers in the wet web of paper, as it is being formed. That mechanism is sometimes called "sealing." The idea is that conformable cellulosic materials are forced together, as a result of applied vacuum or wet-pressing, such that they seal off passageways by which water might have more easily escaped from the wet web (Wildfong et al. 2000). The mechanism is illustrated schematically in Fig. 5.

As in the case of a rubber plug in an old-fashioned sink, the higher the pressure, the more effective becomes the sealing action. McDonald and Amini (1998) were able to apply this type of interpretation to explain dewatering resistance on a linerboard former. Wet sheets were pressed under different pressures in order to estimate the degree to which flow would be sealed off under different conditions of vacuum application during paper formation. Pires et al. (1989) observed cases in which resistance to flow increased out of proportion to the applied pressure, consistent with sealing.

Hubbe and Heitmann (2007). "Water release, papermaking," BioResources 2(3), 500-533. 512 

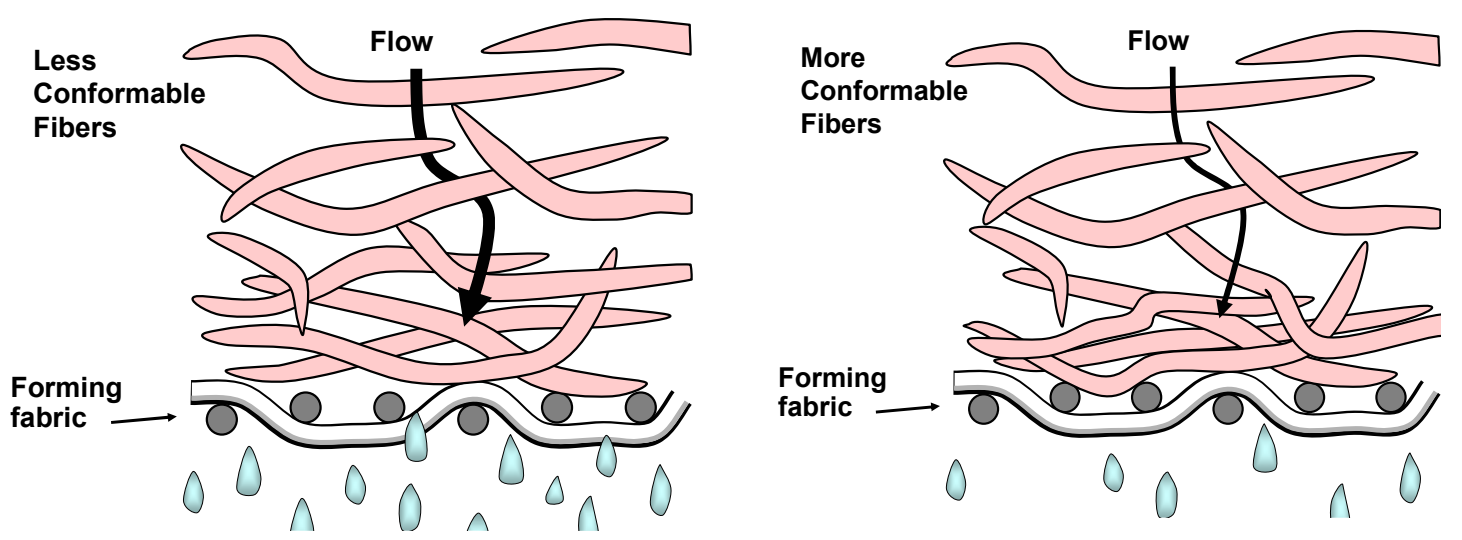

Figure 5. Schematic illustration of "sealing" mechanism in which the fibers in a paper mat are sufficiently flexible that pressure causes them to squeeze together, sealing off flow

Evidence to support a sealing mechanism of resistance to dewatering comes, first of all, from measurements of fiber flexability and conformability (Tam Doo and Kerekes 1982; Steadman and Luner 1985; Paavilainen 1993). More flexible fibers resulted in greater resistance to dewatering. Corroborating evidence comes from studies of fibers that have been recycled under laboratory conditions. An observed increase in freeness when never-dried fibers are formed into paper, dried, and then resuspended in water can be attributed to irreversible stiffening of the fibers (Paavilainen 1993; Dulemba et al. 1999; Zhang et al. 2004).

A sealing mechanism also can help explain the effectiveness of dewatering devices that produce short pulses of applied vacuum. If one assumes that sealing is the dominant mechanism limiting dewatering rates, then one would expect there to be diminishing rates of dewatering whenever vacuum is applied at a steady level (Mitchell and Johnston 2000). Indeed, the most effective dewatering, by means of vacuum flatboxes, usually requires optimization of the spacing and duration of vacuum pulses (Persson and Österberg 1969; Giles 1990; Räisänen 1996; Baldwin 1997). Lindberg (1970) observed that the application of vacuum in the form of pulses became increasingly important with increasing flexibility of the fibers, consistent with a sealing mechanism.

Many papermakers believe that sheet sealing effects mainly can be attributed to an interaction between fibers and the forming fabric. This subject has been reviewed in exquisite detail by Kufferath (1982). The idea is that, especially under conditions of rapid initial dewatering, fibers become pressed into the openings of a forming fabric, effectively rendering the fabric less porous (Giles 1990; Miller 1998). The importance of interactions between a fabric and the initial fibers impinging upon it has been demonstrated by turning a forming fabric upside-down and observing large differences in dewatering performance (Giles 1990). However, another careful study failed to find any special contribution that could be attributed to the first layer of fibers to land on the fabric (Herzig and Johnson 1999). 


\section{INTER-FIBER FRICTION AND ITS INFLUENCE ON DEWATERING}

In addition to the "sealing" mechanism, as just considered, another closely related mechanism appears to play a significant role with respect to the use of dewatering agents. That is, if fibers in a papermaking furnish are able to slide past each other when they come into contact, then one can expect that they will tend to form a relatively dense mat during the forming process. If, on the other hand, they tend to stick together and not slide past each other, then one can expect a more bulky, porous mat of fibers from which water can more easily flow. In other words, the degree to which the furnish components tend to become packed together is expected to play a major role in determining the permeability of the mat that is formed (Sampson and Kropholler 1995).

One way to find out whether fibers in suspension will tend to stick to one another on contact involves rheometric measurements. If the solids content of a fiber suspension is sufficiently high, then it can be feasible to measure the yield strength of a transient network that forms among the fibers upon secession of flow. Swerin et al. (1996) showed that such yield strength values could be greatly increased by the addition of flocculating polymers. At the other extreme, Zauscher (2000) measured frictional forces between submicroscopic surfaces, using atomic force microscopy (AFM). He found that the coefficient of friction generated between pairs of cellulosic surfaces in the presence of water could be greatly reduced by the addition of carboxymethyl cellulose (CMC).

Many of the effects that polyelectrolyte additives can have on inter-fiber friction in the wet state can be understood in terms of electrostatic forces of interaction. A particularly effective way to prevent cellulosic surfaces from sliding easily past one another is to treat the system so that the surfaces are partially covered with "patches" of high-charge cationic polymer. Indeed, polyelectrolytes having suitable molecular mass and high charge that is associated with a patch-type mechanism of agglomeration (Gregory 1976; Goossens and Luner 1976; Akari et al. 1996; Pfau et al. 1999), tend to be effective dewatering aids (Gruber et al. 1996). The general principle of patch-type agglomeration was demonstrated by Das and Lomas (1973), who treated half of a batch of cellulosic fines to make them strongly cationic. When such fines were recombined with untreated fines, having negatively charged surfaces, very strong agglomeration was apparent.

As observed by Noda et al. (2005), substantial decreases in dewatering resistance can be achieved by addition of cationic surface-active agents, which are often used as debonders to reduce the dry strength characteristics of the resulting paper. Because one can expect the positively charged groups on the surfactant to become associated with the negative surfaces of the fibers, it follows that the hydrophobic tails of the molecules will be free to self-associate, especially when a pair of fibers comes into contact. Such a mechanism would be expected to result in higher frictional forces between the fibers. The same mechanism also can explain why fiber mats formed in the presence of cationic surfactants also tend to be much more bulky and porous. Unfortunately, strategies based on the mechanism just described are not suitable for the majority of paper grades, where dry strength usually needs to be relatively high.

Inter-fiber friction also can be evaluated by allowing a treated fiber suspension to settle, and then evaluating the density of the sediment formed after a selected period of 
time and under standardized conditions (Kline 1967; Alince and Robertson 1974; Gruber et al. 1997; Hubbe et al. 2001). Relative to the other test methods, sediment volume tests can sense effects resulting from very small and transient forces of attraction or repulsion between fibers. Treatments that tend to increase values of sediment volume also tend to increase dewatering rates under controlled conditions. The effect is illustrated in Fig. 6.

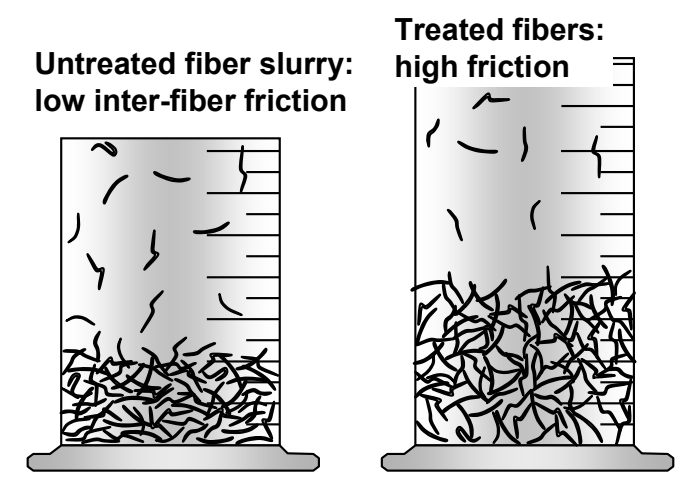

Figure 6. Illustration of sediment volume test with papermaking fibers in the absence and presence of a coagulant

As proposed by Lindström (1989), the most effective polyelectrolyte-based dewatering aid programs tend to be those that can be classed as "reversible." In other words, such systems will tend to form flocs again following application of sufficient hydrodynamic shear to completely redisperse the fibers from each other. The idea is that modern paper machine headboxes and other unit operations exert very strong forces of detachment on fiber systems, causing essentially all of the fiber-to-fiber polymer bridging contacts to be broken at least once before the sheet becomes established in the forming section. But in order for chemical systems to function most effectively as dewatering aids, they need to still have some residual agglomerating ability, even after being subjected to rather intense hydrodynamic shear. In addition to the cationic patch-type treatments already mentioned, microparticle-type drainage aid programs exhibit some reversibility in their flocculation behavior (Lindström 1989; Litchfield 1994; Swerin et al. 1997; Hedborg and Lindström 1996; Hubbe 2001, 2005).

\section{FIBER ALIGNMENT AND FLOW RESISTANCE}

If one could align wet fibers in the manner that combed wet hair becomes aligned, then it is likely that one could achieve a significant decrease in permeability through a fiber mat. Such a mechanism even may be responsible for the "sheet sealing" effects described earlier. Evidence for this kind of mechanism has been obtained in studies where dewatering occurred in the presence of controlled hydrodynamic shear (Forsberg and Bengtsson 1990; Arslan et al. 1997; Paradis et al. 2003). For instance, controlled shear could be applied by using a rotor having the shape of a shallow cone positioned close to the dewatering screen (Paradis et al. 2003). 
As a counter-example, is appears that significantly more permeable wet paper mats can be created under conditions where the fiber orientation is chaotic, including a high degree of out-of-plane alignment. It is well known that such chaotic alignment can be achieved by forming paper at relatively high solids content of the suspension. Paper formed under such conditions has been shown to have a reduced resistance to dewatering (Ingmanson and Whitney 1954; Ellis 1981).

\section{PAPER UNIFORMITY AND VACUUM RESPONSE}

The remaining experimental evidence that will be considered has particular relevance to vacuum dewatering, in addition to dewatering within wet-press nips. In a classic piece of investigation Britt and Unbehend (1980) demonstrated positive effects of various dewatering aid treatments on the release of water during simple gravity-filtration of fiber suspensions. But parallel tests, carried out with application of vacuum, gave contradictory results. Rather than aiding in the dewatering, the cationic polymers, when used alone or in combination with an anionic acrylamide-type retention aid, resulted in substantially wetter fiber mats following a standardized application of vacuum.

The inconsistent results were attributed to the formation of persistent fiber flocs by the polyelectrolyte treatments. More rapid dewatering by gravity was achieved due to the ability of water to flow quickly within the large void spaces that surround fiber flocs. But once most of the water has been removed by application of vacuum, the same void spaces allow air to rush ineffectively through the wet web, failing to maintain a pressure differential across the thickness of the sheet. Confirmatory results were obtained by Scalfarotto and Tarvin (1984) and by Wegner (1987). The latter study also showed that the more highly flocculated sheets required longer application of heat in the drying operation in order to evaporate the remaining water.

Britt (1981) recommended at least moderate levels of refining of kraft fibers, in addition to vigorous agitation, in order to achieve uniform formation, as is required for an efficient response to vacuum application. Also, as observed by Britt and Unbehend (1985), the presence of a moderate level of fiber fines in the furnish can significantly improve vacuum dewatering, in comparison to a furnish from which the fines fraction has been removed. Not only do fiber fines tend to fill in void spaces within a wet web of paper, but also, as shown by Youn and Lee (2002), fines in the suspension can reduce the tendency of fibers to flocculate. All of these results are consistent with the formation of a tight, uniform wet-web that does not allow rapid leakage of air. Follow-up experiments on a pilot-scale paper machine showed that the most rapid dewatering could be obtained if, after addition of a highly effective flocculant system, including a highly charged cationic polymer, the furnish was agitated vigorously to fully disperse the fibers from each other (Britt and Unbehend 1980).

As one gets towards the upper limit of solids content that can be achieved by application of vacuum, it can be expected that a significant fraction of the water remaining within paper exists in thin films that occupy spaces between adjacent fibers and other solids (Maloney et al. 1999). Such films can help to explain why plugs of moist fiber that have been subjected to centrifugation tend to be wettest in the lower 
layer, where the fibers were pressed together most tightly during dewatering (Abson and Gilbert 1980). As noted by Jones (1998) one can expect vacuum dewatering, at a given pressure differential, to reach a maximum, when all of the pores larger than a critical size have been emptied. Capillary pressures, which are inversely proportional to effective pore radius, can make it impossible to empty smaller pores.

\section{PUMPING AS A DEWATERING MECHANISM}

As already noted, the washing action of hydrofoils may tend to counter-act the choke-point mechanism of resistance to dewatering. However, there is a further effect of pulsating vacuum that may play a role once the wet web reaches the vacuum dewatering section of the forming zone. Räisänen et al. (1995) proposed that the part of the wet web nearest to the forming fabric can act as a sort of pump. The way in which this happens is by the layer becoming strongly compressed, when the wet web passes over a slot in a vacuum box. As the compressed layer recovers its equilibrium thickness, it may draw water from the rest of the wet web. The mechanism is supported by the relative futility of applying an individual vacuum pulse too long at a given pressure (Baldwin 1997; Jones 1998). Such a practice might be compared to application of further pressure to a spring after it has become almost fully compressed.

\section{WATER HELD WITHIN FIBERS}

An even more difficult to remove category of water exists within the cell walls of fibers. As mentioned already, such water is commonly estimated by centrifugation of a damp plug of fibers, weighing the damp fibers, and then weighing them again after oven drying (Thode et al. 1960; Jame and Büttel 1968; Scallan and Carles 1972; Scallan and Tigerstrom 1992; Anon. 1981, 2000). The results of such tests are expressed as the water retention value (WRV), which is the ratio of water to fiber solids after centrifugation for a specific time at a specified level of acceleration (Anon. 1981, 2000). Cell-wall water content also can be evaluated by suspending a known mass of fibers in a known mass of water that contains a known concentration of high-mass dextran polymers (Scallan and Carles 1972; Scallan and Tigerstrom 1992; Maloney et al. 1999). One makes the assumption that the dextran molecules are too large to enter small pores within the cell walls of fibers and that they have no significant tendency to adsorb onto cellulose. By measuring the concentration of the sugar molecules in the bulk phase, one then back-calculates what must have been the net volume of pores that were too small to allow entrance of the polymers. Such a method even has been applied in the case of fiber fines, showing that recycled and rewetted fines tend to hold onto much less water, compared to their swollen state before their first cycle of drying (Laivins and Scallan 1996).

It appears doubtful that the swollen state of cellulosic materials can be affected to a significant extent by addition of dewatering aids, though more experimental evidence is needed. Swerin et al. (1990) reported significant decreases in water retention value following treatment of refined fiber suspensions with highly cationic polyelectrolytes of

Hubbe and Heitmann (2007). "Water release, papermaking," BioResources 2(3), 500-533. 517 
low to moderate molecular mass. However, related results obtained by Ström and Kunnas (1993) provide evidence that most of the effect of such polyelectrolytes is restricted to a dewatering effect involving fibrillated layers. The mechanism is illustrated in Fig. 6, which depicts coagulation of a fibrillated layer by cationic polyelectrolyte molecules, though it is assumed that such molecules do not readily penetrate into the nanopores of the cell wall. As was noted earlier, the greater effectiveness of higher-mass polyelectrolytes in reducing the WRVs of treated suspensions probably can be attributed to enhanced effectiveness of the charged-patch mechanism of agglomeration, as well as a decreased tendency for the polyelectrolytes to become buried within smaller pores.
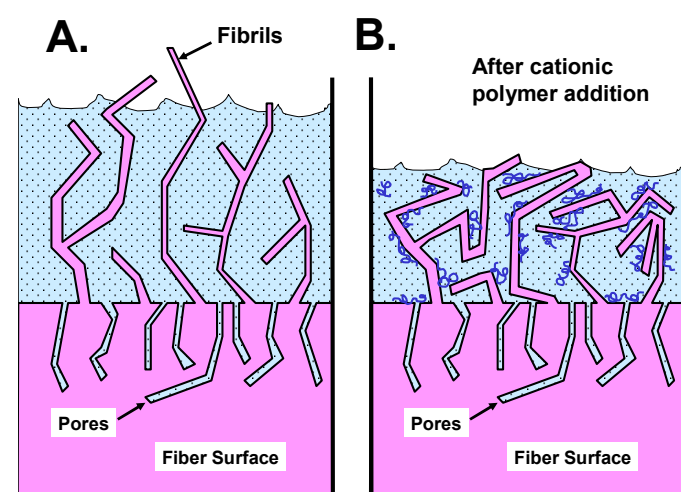

Figure 7. Illustration of how the coagulating effect of high-charge cationic additive (possibly acting by a charged patch mechanism) might decrease the amount of water held within layers of fibrils at fiber surfaces.

Some limited research has suggested that significant amounts of water can be associated with water-soluble polymers or polymer complexes held within a wet web of paper. For instance, Carlsson et al. (1977) measured significant increases in water retention with increasing levels of cationic acrylamide copolymer addition to mechanical pulp slurries. Hubbe et al. (2007b) observed increases in water retention when glass microfibers were treated with polyampholytes, which are polyelectrolytes having both negative and positive ionic groups. Further research is needed to determine whether such effects can be significant over a broad range of polyelectrolyte types and furnish conditions.

\section{COMPRESSION RESISTANCE AND WET-PRESS DEWATERING}

It can be very challenging in the laboratory to estimate the maximum practical solids levels that can be achieved by wet-pressing of paper. Tests involving application of static pressure are not expected to give realistic predictions, due to the very short periods of time during which a wet web passes through a press nip. A number of researchers have attempted to evaluate wet-press dewatering by using devices that apply a hammer-like impulse (Zotterman and Wahren 1978; Davis et al. 1983; Carlsson 1984; Springer et al. 1989). Tests of wet-press dewatering generally have failed to show significant effects that could be attributed to prior treatment of the furnish with chemical 
additives (Wegner 1987), though it is quite likely that the noise-to-signal ratio within the data would have obscured any such effects.

When a wet web of paper passes through a press nip, two types of forces are mainly responsible for preventing crushing of the sheet. One of these components of force results from hydrostatic pressure. Such pressure is a direct consequence of the factors that resist dewatering, i.e. frictional effects as water is squeezed through narrow passageways. But in addition to the hydrostatic component, the compressive forces also are resisted by the mechanical strength of solid components within the paper web (MacGregor 1983ab; Szikla and Paulapuro 1989). The interplay between these two classes of forces helps to explain, among other things, why paper sheets tend to become highly densified in the layers that lie nearest to a porous felt as the sheet passes through a press nip.

Very little research has been carried out to determine whether or not papermaking additives can contribute to the structural component of compression resistance in a wet web of paper. As an exception to this rule Fairchild (1992) showed that paper manufactured with a highly bulky, rosette-shaped form of precipitated calcium carbonate (PCC) filler tended to retain more water content after pressing, in comparison to paper that was made with PCC having a less bulky particle shape.

In the production of many paper grades, and in particular xerographic copy paper, file folder stock, and folding boxboard, it can be a great advantage to maintain a low apparent density in the final product. The challenge comes in trying to figure out how to press water effectively from a wet web of paper without irreversibly densifying it. One of the most promising strategies, in this regard, appears to involve the use of spring-like fibers, having the ability to recover some of their initial three-dimensional character after being squashed flat in a press nip. In this regard, mechanical pulp fibers usually can be described as being "tougher" in comparison to kraft fibers. For instance, it has been proposed to use chemithermomechanical pulp (CTMP) fibers in order to compensate for increased density when paper is prepared with a very high mineral content (Moberg 1985). Another approach involves directing the jet of fiber suspension at a relatively steep angle of impingement onto the forming fabric, i.e. pressure forming. By such means it is possible to achieve a higher proportion of fibers having orientations other than in the plane of the sheet. In principle, one expects there to be a relationship between outof-plane fiber orientation and the ease of dewatering from paper. Issues of this nature deserve greater study in the future.

\section{PRACTICAL STRATEGIES FOR DEWATERING OF PAPER}

Having discussed many different contributing mechanisms to explain the resistance to water release from paper, as it is being formed, this final section will be devoted to a summary of the main strategies that have been used to accelerate such dewatering. The goal here is to translate some of the chemical-related concepts outlined in this review to practical measures that can be implemented in a paper machine system. Items in the following list are arranged roughly in the same order as in the foregoing discussion: 
Table 1. Common Strategies for Promoting Faster Dewatering

\begin{tabular}{|l|l|}
\hline Dewatering Enhancement Strategy & Principle of Action \\
\hline Minimize refining & Surface area minimization; keeping fibers stiff \\
\hline Limited furnish treatment with cellulase & Reducing hydrodynamic surface area \\
\hline Heat up the wet web (steam box) & Reducing viscosity of aqueous solution \\
\hline Add high-charge cationic polymer or alum & Coagulation of fiber fines and fibrils. \\
\hline Aim for near-zero zeta potential of solids & " \\
\hline Use a high-mass polyelectrolyte flocculant & Attaching fiber fines so they can't choke channels \\
\hline Use once-dried fibers, without more refining & Stiffer fibers forming a bulkier, more porous mat \\
\hline Agitate flocculated fiber suspension & Breaking up fiber-to-fiber attachments \\
\hline Employ microparticle retention chemistry & Optimizing reversible attachments, friction \\
\hline Use filler having less structure & Less resistance to sheet compression \\
\hline Use filler having less surface area & Less viscous resistance to water flow in web \\
\hline
\end{tabular}

In summary, most of the principles outlined in this review have the potential to be implemented during industrial operations. Though the mixtures of materials and the flow environments present in a paper machine system generally are too complex to be described in scientific detail, enough is known about the underlying mechanisms to allow an efficient search for new and better means of promoting the release of water. This kind of technology will continue to hold promise for further savings in evaporative energy, as well as for increasing the rates of production on existing papermaking equipment.

\section{REFERENCES CITED}

Abe, E., Hirosue, H., and Yokota, A. (1979). "Pressure drop through a packed bed of binary mixture," J. Chem. Eng. Japan 12, 302-306.

Abson, D., Bailey, R., Lenderman, C., Nelson, J., and Simons, P. (1980). "Predicting the performance of shear-sensitive additives," Tappi 63(6), 55-58.

Abson, D., and Gilbert, F. D. (1980). "Observation on water retention values," Tappi 63(9), 146-147.

Ahrens, F., Alaimo, N., Nanko, H., Patterson, T. (1999). "Initial development of an improved water retention value test and its application to the investigation of water removal potential," TAPPI 1999 Proc., 37.

Akari, S., Screpp, W., and Horn, D. (1996). "Imaging of single polyethylenimine polymers adsorbed on negatively charged latex spheres by chemical forces microscopy," Langmuir 12(4), 857-860.

Alince, B., and Robertson, A. A. (1974). "Aggregation of microcrystalline cellulose with polyethyleneimine," Colloid Polymer Sci. 252, 920-927.

Allen, L. H. (1985). "Particle size distributions of fines in mechanical pulps and some aspects of their retention in papermaking," Tappi 68 (2), 91-94 (1985).

Allen, L. H., and Yaraskavitch, I. M. (1991). "Effects of retention and drainage aids on paper machine drainage: A review," Tappi J. 74 (7), 79-84.

Andersson, K., Sandström, A., Ström, K., and Barla, P. (1986). "The use of cationic starch and colloidal silica to improve the drainage characteristics of kraft pulps," Nordic Pulp Paper Res. J. 1(2), 26-30. 
Andrade, J. S., Behyania, F., Foumeny, E. A., McGreavy, C., and Rajagopal, K. (1992).

"On the permeability of binery packings of spheres," Chem. Eng. Technol. 15, 11-14.

Anon. (1981). "Water retention value," TAPPI Useful Method UM 256.

Anon. (1994a). "Freeness of pulp (Canadian standard method)," TAPPI Test Methods, TAPPI Press, Atlanta, T227.

Anon. (1994b). "Fines fractionation of paper stock by wet screening," TAPPI Test Methods T, TAPPI Press, Atlanta, $261 \mathrm{~cm}-94$.

Anon. (2000). "Water retention value," SCAN Test Method SCAN-C 62:00.

Anon. (1995). "Fiber length of pulp by classification," TAPPI Test Methods, TAPPI Press, Atlanta, T $233 \mathrm{~cm}-95$.

Arslan, K., Bousfield, D. W., and Genco, J. M. (1997). "Effect of shear forces on fine particle retention," Tappi J. 80(1), 254-261.

Auhorn, W. (1982). "Sheet forming, dewatering, drying - Improved by means of chemistry," Wochenbl. Papierfabr. 110(5), 155-162.

Baldwin, L. (1997). "High-vacuum dewatering," Paper Technology 38(4), 23-28.

Bear, J. (1972). Dynamics of Fluids in Porous Media, Dover Publ., New York.

Bhardwaj, N. K., Kumar, S., and Bajpai, P. K. (2005). "Effect of zeta potential on retention and drainage of secondary fibers," Colloids Surf. A. 260(1-3), 245-250.

Binotto, A. P., and Nicholls, G. A. (1979). "Correlation of morphological variations in pulps with filtration resistance, specific volume, and specific surface," Appita 33 (3), 185-188 (1979).

Blechschmidt, J., Mallon, U., and Schramm, S. (2000). "Quantitative assessment of fines in paper manufacture," Wochenblatt Papierfabr. 128 (5), 300-305 (2000).

Bley, L., and Falkenberg, W. (2001). "Dynamic drainage measurement - A quick, expressive, and automated method," Proc. TAPPI Papermakers Conf., 975-1001.

Bliss, T. (1996). "Centrifugal cleaning in the stock preparation system," in Stock Preparation Course Notes, TAPPI Press, Atlanta, 33-40.

Bliss, T. (1996). "Screening in the stock preparation system," in Stock Preparation Short Course Notes, TAPPI Press, p. 171.

Brecht, W., and Kirchner, U. (1959). “Air content of pulp suspensions," Wochenbl. Papierfabr. 87(8), 295-305.

Brecht, W., and Klemm, K. (1953). "The mixture of structures in a mechanical pulp as a key to the knowledge of its technical properties," Pulp Paper Mag. Can. 54(1), 72-80.

Britt, K. W. (1981). "Paper sheet formation: Observations concerning retention," Tappi 64(5), 53-55.

Britt, K. W. (1981). "Observations on water removal during the papermaking process," Tappi 64(6), 55-56.

Britt, K. W., and Unbehend, J. (1980). "Water removal during sheet formation," Tappi J. 63(4), 67-70.

Britt, K. W., and Unbehend, J. (1985). "Water removal during paper formation," Tappi J. 68(4), 104-107 (1985).

Britt, K. W., Unbehend, J. E., and Shridharan, R. (1986). "Observations on water removal in papermaking," Tappi J. 69(7), 76-79. 
Brouillette, F., Marneau, D., Chabot, B., and Daneault, C. (2005). "A new microparticulate system to improve retention/drainage in fine paper manufacturing," Appita J. 58(1), 47-51.

Cadotte, M., Tellier, M.-E., Blanco, A., van de Ven, T., and Paris, J. (2005). "Effects of various retention aids on fiber flocculation, filler retention and drainage," Ann. Mtg. Pulp Paper Tech. Assoc. Canada (PAPTAC), Vol. A, A31-A38.

Carlsson, G. (1984). "Press simulator - A new tool for wet-pressing studies," Svensk Paperstidn. 87(15), 22-26, 29-32, 35.

Carlsson, G., Lindström, T., and Söremark, C. (1977). "The effect of cationic polyacrylamides on some dry strength properties of paper," Svensk Papperstidn. 80(6), 173177.

Carman, P. C. (1938). "Fluid flow through granular beds," Trans. Inst. Chem. Engrs. (London) 16, 168-188.

Carman, P. C. (1939). "Determination of the specific surface of powders. Part 2," J. Soc. Chem. Ind. 58, 2-7.

Carrier, W. D. (2002). “Goodby, Hazen; Hellow, Kozeny-Carman,” J. Geotech. Geoenviron. Eng. (Nov.), 1054-1056.

Chan, A. K. T., Pelton, R. H., Zhu, S., and Baird, M. H. I. (1996). "The effects of polystyrene beads and nylon fibers on the permeability of compressed wood fiber pads," Can. J. Chem. Eng. 74, 229-235.

Chapuis, R. P., and Auberton, M. (2003). "On the use of the Kozeny-Carman equation to predict the hydraulic conductivity of soils," Can. J. Geotech. 40: 616-628.

Corscadden, K. W., Brewster, D. B., and Pascal, H. (2005). "Intelligent drainage analysis: A case study," Annual Meeting of the Pulp and Paper Technical Association of Canada (PAPTAC), Vol. C, C127-C133.

Corson, S. R. (1980). "Fiber and fines fractions influence strength of TMP," Pulp Paper Can. 81(5), T108-T112.

Das, S., Cresson, T., and Couture, R. (1999). "New pulp characterization from drainage, fiber flexibility and RBA," Proc. 85 ${ }^{\text {th }}$ Ann. Mtg. PAPTAC, A345-A347.

Das, B. S., and Lomas, H. (1973). "Flocculation of paper fines. I. Adsorption of and flocculation by polyelectrolytes. II. Study of the nature of the solid surface and soluble impurities," Pulp Paper Can. 74(8), 95-100.

Davis, E. J., Stratton, R. A., and Chang, N. L. (1983). "Water removal studies with the wet press simulator," J. Pulp Paper Sci. 9(3), TR68-TR73.

Deodhar, S., and Luner, P. (1980). "Measurement of bound (nonfreezing) water by differential scanning calorimetry," ACS Symp. Ser. 127, Water in Polymers, S. P. Rowland (ed.), Ch. 16, 273-286.

De Silveira, G., Zhang, X., Berry, R., and Wood, J. R. (1996). "Location of fines in mechanical pulp handsheets using scanning electron microscopy," J. Pulp Paper Sci. 22(9), J315-320.

Dodds, J. A. (1980). "The porosity and contact points in multicomponent random sphere packings calculated by a simple statistical geometric model," J. Colloid Interface Sci. 77(2), 317-327.

Doiron, B. E. (1998). "Retention aid systems," in Retention of Fines and Fillers during Papermaking, J. M. Gess (ed.), TAPPI Press, Atlanta, Ch. 8, 159-176. 
Doshi, M. R. (1998). “Take care of your fines, please," Prog. Paper Recycling 7 (4), 8.

Dulemba, M., Qi, D., and Aravamuthan, R. (1999). "The effect of repeated drying and wetting on single fiber flexibility," Prog. Paper Recycling 9(1), 38-45.

Dunham, A. J., Sherman, L. M., and Alfano, J. C. (2002). "Effect of dissolved and colloidal substances on drainage properties of mechanical pulp suspensions," J. Pulp Paper Sci. 28(9), 298-304.

Egelhof, D., and Bubik, A. (1994). "The influence of mechanical equipment on sheet formation," Wochenbl. Papierfabr. 122(4), 111-117.

Ellis, E. P., Jr. (1981). "Compressibility and permeability of never dried bleached softwood kraft pulp and its application to the prediction of wet press," Ph.D. thesis, University of Maine, Orono, ME.

Eriksson, L. A., Heitmann, J. A., Jr., and Venditti, R. A. (1997). "Drainage and strength properties of OCC and ONP using enzymes with refining," Proc. TAPPI Recycling Symp., 423-434.

Eriksson, L. A., Heitmann, J. A. Jr., and Venditti, R. A. (1997). "Freeness improvement of recycled fibers using enzymes with refining," in Enzyme Applications in Fiber Processing, ACS Vol. X.

Ethier, C. R. (1991). "Flow through mixed fibrous porous materials," AIChE J. 37, 12271236.

Fairchild, G. H. (1992). "Increasing the filler content of PCC-filled alkaline papers," Tappi J. 75(8), 85-90.

Fjerdingen, H., and Houen, P. J. (1997). "On the effect of recycling of kraft paper on selected fines properties," Recyc. Symp., 299-312.

Forsberg, S., and Bengtsson, M. (1990). "The Dynamic Drainage Analyser (DDA)," Proc. TAPPI 1990 Papermakers Conf., TAPPI Press, Atlanta, 239-245.

Forsberg, S., and Ström, G. (1994). "The effect of contact time between cationic polymers and furnish on retention and drainage," J. Pulp Paper Sci. 20(3), J71-J76.

Foulger, M. (1996). "Submerged drainage: New concept in dewatering," Paper Technol. $37(2), 35-38$.

Gerber, P. J., Joyce, T. W., Heitmann, J. A., Siika-aho, M., and Buchert, J. (1997). "Adsorption of a Trichoderma reesei endoglucanase and cellobiohydrolase onto bleached kraft fibers," Cellulose 4(4), 255-268.

Gertjejansen, R., and Hossfeld, R. (1967). "Gas-liquid relationships and their effect upon the permeability of wood pulp pads to water," Tappi 50(4), 204-208.

Gess, J. M. (1984). “A new drainage analysis system,” Tappi J. 67(3), 70-72.

Gess, J. M. (1991). “The fines sensitivity of papermaking furnishes," TAPPI 1991 Advanced Topics Wet-End Chem. Short Course Notes, TAPPI Press, Atlanta, 70.

Gess, J. M. (1993). "The effect of anionic polymers and mixing time on the drainage characteristics of a papermaking pulp," Proc. TAPPI 1993 Papermakers Conf., TAPPI Press, Atlanta, 79-85.

Giles, A. F. (1990). "Practical comments on paper machine drainage," Tappi J. 73(9), 123-129.

Gong, M.-R., and Bi, S.-L. (2005). "Mechanism of drainage improvement of bleached wheat pulp by the functioning of cellulase," China Pulp Paper 24(3), 1-4. 
Gong, M., Bi, S., Sun, J., Xue, Y., and Cheng, J. (2003). "Improving drainage of OCC pulp by complex cellulose," China Pulp Paper 22(1), 14-16.

Görres, J., Amiri, R., Wood, J. R., and Karnis, A. (1996). "Mechanical pulp fines and sheet structure," J. Pulp Paper Sci. 22(12), J491-J496.

Goossens, J. W. S., and Luner, P. (1976). "Flocculation of microcrystalline cellulose suspensions with cationic polymers: Effect of agitation," Tappi J. 59(2), 89-94.

Gregory, J. (1976). "The effect of cationic polymers on the colloidal stability of latex particles," J. Colloid Interface Sci. 55(1), 35-44.

Gruber, E., and Gelbrich, M. (1997). "Effects of enzymatic and chemical drainage aids. Part 1. Freeness and water retention," Papier 51(4), 166-174.

Gruber, E., Gelbrich, M., and Schempp, W. (1997). "Morphological and chemical effects on drainage," Wochbl. Papierfabr. 125(2), 66-72.

Gruber, E., Grossmann, K., and Schemp, W. (1996). "Interactions of synthetic cationic polymers with fibers and fillers. 2. Effects on dewatering and retention," Wochenbl. Papierfabr. 124(3), 102-105.

Han, S. T. (1969). "Compressibility and permeability of fiber mats," Pulp Paper Mag. Can. 70(9), T134-T146, 65-77.

Han, S. T., and Ingmanson, W. L. (1967). “A simplified theory of filtration,” Tappi 50(4), 176-180.

Haslam, J. H., and Steele, F. A. (1936). "The retention of pigments in paper," Tech. Assoc. Papers 19, 249-252.

Hawes, J. M., and Doshi, M. R. (1986). "The contribution of different types of fines to the properties of handsheets made from recycled paper," Proc. TAPPI 1986 Pulping Conf., 613.

Heath, H. D., and Hofreiter, B. T. (1978). "Filler-retention and dry-strength additives. A modified handsheet evaluation procedure," Tappi 61(12), 21-23.

Helle, T.-M., and Paulapuro, H. (2004). "Effect of precipitated gas bubbles in papermaking," Appita J. 57(6), 444-447.

Herzig, R. and Johnson, D. B. (1999). "Investigation of thin fiber mats formed at high velocity," Tappi J. 82(1), 226-230.

Horn, D., and Linhart, F. (1991). "Retention aids," in Paper Chemistry, J. C. Roberts (ed.), Blackie, Glasgow, UK, Ch. 4, 44-62.

Horn, D., and Melzer, J. (1975). "Influence of high-molecular cationic dewatering agents on electrokinetic properties of pulp," Papier 29(12), 534.

Htun, M., and de Ruvo, A. (1978). "The implication of the fines fraction for the properties of bleached kraft sheet," Svensk Papperstidn. 81(16), 507-510.

Hubbe, M. A. (1984). "Theory of detachment of colloidal particles from flat surfaces exposed to flow," Colloids Surf. 12(1-2), 151-178.

Hubbe, M. A. (1985). "Detachment of colloidal hydrous oxide spheres from flat solids exposed to flow. 2. Mechanism of release," Colloids Surf. 16(3-4), 249-270.

Hubbe, M. A. (1987). "Detachment of colloidal hydrous oxide spheres from flat solids exposed to flow. 4. Effects of polyelectrolytes," Colloids Surf. 25, 325-339.

Hubbe, M. A. (2000). "Reversibility of polymer-induced fiber flocculation by shear. 1. Experimental methods," Nordic Pulp and Paper Res. J. 15(5), 545-553; 16(4), 375. 
Hubbe, M. A. (2001). "Reversibility of polymer-induced fiber flocculation by shear. 2. Multicomponent chemical systems," Nordic Pulp and Paper Res. J. 16(4), 369-375.

Hubbe, M. A. (2002). "Fines management for increased paper machine productivity," Proc. Sci. Tech. Advan. Wet End Chem., PIRA, Vienna, Paper 3.

Hubbe, M. A. (2003). "Selecting laboratory tests to predict effectiveness of retention and drainage aid programs," Paper Technol. 44(8), 20-34.

Hubbe, M. A. (2005). "Microparticle programs for drainage and retention," in Rodriguez, J., Ed., Nano- Microparticle Technology, Chapter 1, TAPPI Press, Atlanta.

Hubbe, M. A. (2006). "Sensing the electrokinetic potential of cellulosic fiber surfaces," BioResources 1(1), 116-149.

Hubbe, M. A., Heitmann, J. A., Venditti, R. A., and Tripattharanan, T. (2006a). "The 'positive pulse jar' (PPJ): A flexible device for retention studies," Paperi Puu 88(1), $39-45$.

Hubbe, M. A., Rojas, O. J., Argyropoulos, D. S., Wang, Y., Song, J., Sulić, N., and Sezaki, T. (2006b). "Charge and the dry-strength performance of polyampholytes. Part 2. Colloidal effects," Colloids Surf. A., in press.

Hubbe, M. A., Rojas, O. J., Lucia, L. A., and Jung. T. M. (2007a). "Consequences of the nanoporosity of cellulosic fibers on their streaming potential and their interactions with cationic polyelectrolytes" Cellulose, accepted.

Hubbe, M. A., Rojas, O. J., Sulić, N., and Sezaki, T. (2007b). "Unique behavior of polyampholytes as dry-strength additives," Appita J. 60(2), 106-112, 128.

Hubbe, M. A., and Wang, F. (2002). "Where to add retention aid: Issues of time and shear," Tappi J. 1(1), 28-33.

Huber, P., Pierre, C., Bermond, C., and Carré, B. (2004). "Optimizing the running conditions of several wet-end retention systems," Proc. Wet End Chemistry, Pira, Letherhead, Surrey, UK.

Ingmanson, W. L. (1952). "An investigation of the mechanisms of water removal from pulp slurries," Tappi 35(10), 439-448.

Ingmanson, W. L. (1953). "Filtration resistance of compressible materials," Chem. Eng. Progr. 49(11), 577-584.

Ingmanson, W. L. (1964). "Filtration of high consistency fiber suspensions," Tappi 47(12), 742-750.

Ingmanson, W. L., and Andrews, B. D. (1959). "The effect of beating on filtration resistance and its components on specific surface and specific volume," Tappi 42(1), 2935.

Ingmanson, W. L., and Whitney, R. P. (1954). "The filtration resistance of pulp slurries," Tappi 37(11), 523-534.

Iwanow, S. N., and Ljadowan, W. (1970). "Investigation of the mechanism of filler retention in paper," Zellstoff Papier 19(4), 101-105.

Jackson, G. W., and James, D. F. (1986). "The permeability of fibrous porous media," Can. J. Chem. Eng. 64(3), 364-374.

Jackson, L. S., Heitmann, J. A., Jr., and Joyce, T. W. (1994). "Visualization of enzyme binding to secondary fiber silver-enhanced colloidal gold," Prog. Paper Recycling $3(2), 32-41$. 
Jackson, L. S., Joyce, T. W., Heitmann, J. A., and Giesbrecht, F. G. (1996). “Enzyme activity recovery from secondary fiber treated with cellulase and xylanase," $J$. Biotechnol. 45, 33-44.

Jaycock, M. J., and Pearson, J. L. (1976). "Study of the retention of pigment during paper formation," J. Colloid Interface Sci. 55(1), 181-190.

Jaycock, M. J., Pearson, J. L., Counter, R., and Husband, F. W. (1976). "Effect of cellulose fiber fines on the retention of fillers," J. Appl. Chem. Biotechnol. 26(7), 370-374.

Jaycock, M. J., and Swales, D. K. (1994). "The theory of retention," Paper Technol. 35(8), 26-33.

Jayme, G., and Büttel, H. (1968). "Concerning the determination and meaning of water retention value of various bleached and unbleached cellulosic pulps," Wochenbl. Papierfabr. 96(6), 180-187.

Jones, G. L. (1998). "Dynamic simulation of dewatering in high vacuum flat boxes," Proc. TAPPI Intl. Engineering Conf., TAPPI Press, Atlanta,Vol. 1, 325-334.

Jonsson, K. A.-S., and Jonsson, B. T. L. (1992). "Fluid flow in compressible porous media: 1. Seady-state conditions," AIChE J. 38(9), 1340-1348.

Jonsson, K. A.-S., and Jonsson, B. T. L. (1992). "Fluid flow in compressible porous media: 2. Dynamic behavior," AIChE J. 38(9), 1349-1356.

Kang, T., and Paulapuro, H. (2006). "Characterization of chemical pulp fines," Tappi J. 5(2): 25-28.

Karras, M., and Springer, A. M. (1989). "Influence of aeration and polymer on drainage of pine kraft slurries," Tappi J. 72(2), 155-159.

Kerekes, R. J., and Harvey, D. M. (1980). “TAPPI Fluid Mechanics Committee drainage tester survey," Tappi 63(5), 89-91.

Kibblewhite, R. P. (1975). "Interrelations between pulp refining treatments, fiber and fines quality, and pulp freeness," Paperi Puu 57(8), 519-522, 525-526.

Kline, J. E. (1967). "The application of the Verwey-Overbeek theory to the relative sediment volume of kaolin-water dispersions," Tappi 50(12), 590-596.

Klungness, J. H., and Caulfield, D. F. (1982). "Mechanisms affecting fiber bonding during drying and aging of pulps," Tappi J. 65(12), 94-97.

Kozeny, J. (1927). "About capillaries conducting water in the earth," Sitzber. Akd. Wiss. Wien, Math. Naurv. Kasse 136(Abl. 2a), 271-306.

Krogerus, B., Fagerholm, K., and Tiikkaja, E. (2002). "Fines from different pulps compared by image analysis," Nordic Pulp Paper Res. J. 17(4), 440-444.

Kufferath, W. (1982). "Dewatering events on the paper machine," Deutsche Paperierwirtschaft 1982(2), 61-82; (3), 143-163; (4), 151-160; 1983(1), 63-74.

Kugge, C., Bellander, H., and Daicic, J. (2005). "Pressure filtration of cellulose fibers," J. Pulp Paper Sci. 31(2), 95-100.

Kumar, P. and Ramarao, B. V. (1995). "Characterization of permeability, compressibility, and the specific filtration resistance of papermaking pulps," Proc. TAPPI Papermakers Conf., TAPPI Press, Atlanta, 465-490.

Kumar, P., Wei, H. L., and Ramarao, B. V. (1996). "A model for freeness measurement of papermaking suspensions," Chem. Eng. Commun. 1996, 152-153, 287-306.

Kyan, C. P., Wasan, D. T., and Kintner, R. C. (1970). "Flow of single-phase fluids through fibrous meds," Ind. Eng. Chem. Fundam. 9(4), 596-603. 
La Mer, V. K., and Healy, T. W. (1963). "Adsorption-flocculation reactions of macromolecules at the solid-liquid interface," Rev. Pure Appl. Chem. 13(Sept.), 112-133.

Laivins, G. V., and Scallan, A. M. (1996). "The influence of drying and beating on the swelling of fines," J. Pulp Paper Sci. 22(5), J178-J184.

Lappan, R. E., Hrymak, A. N., and Pelton, R. (1996). "Polymer enhanced brownstock washing: Mill trial," Tappi J. 79(11), 170-178.

Lee, P. F. W., and Lindström, T. (1989). "Effects of high molecular mass anionic polymers on paper sheet formation," Nordic Pulp Paper Res. J. 4(2), 61-70.

Liimatainen, H., Kokko, S., Rousu, P., and Niinimaki, J. (2006). "Effect of PCC filler on dewatering of fiber suspension," Tappi J. 5(11), 11-16.

Lin, J. T., and Schuster, M. A. (1992). "Predicting drainage, retention, and formation development on high ash alkaline paper machines," Proc. 1992 Papermakers Conf., TAPPI Press, Atlanta, 253-266.

Lindberg, L. (1970). "Pulsed drainage of paper stock," Svensk Papperstidn. 73(15), 451454.

Lindholm, C.-A. (1980). "Comparison of some papermaking properties of groundwood, pressure groundwood and thermomechanical pulp by means of artificial blends of pulp fractions. Part 2. The fines fractions," Paperi Puu 62(12), 803-808.

Lindholm, C.-A. (1983). "Determining optimum combinations of mechanical pulp fractions. Part 2. Optimization of the composition of SGW, PGW, and TMP pulps," Paperi Puи 65(6-7), 404-409.

Lindsay, J. D. (1994). "Relative flow porosity in fibrous media: Measurements and analysis, including dispersion effects," Tappi J. 77(6), 225-239.

Lindsay, J. D., and Brady, P. H. (1993a). "Studies of anisotropic permeability with applications to water removal in fibrous webs. Part 1," Tappi 76(9), 119-127.

Lindsay, J. D., and Brady, P. H. (1993b). "Studies of anisotropic permeability with applications to water removal in fibrous webs. Part 2," Tappi 76(11), 167-174.

Lindström, T. (1989). "Some fundamental chemical aspects of paper forming," in Fundamentals of Papermaking, Trans. ${ }^{\text {th }}$ Fund. Res. Symp., Cambridge, C. F. Baker and V. W. Punton (eds.), Mechanical Engineering Publ., Ltd., London, 311-412.

Lindström, T., and Carlsson, G. (1982). "The effect of carboxyl groups and their ionic form during drying on the hornification of cellulose fibers," Svensk Papperstidn. 85(15), R146-R151.

Litchfield, E. (1994). "Dewatering aids for paper applications," Appita 47(1), 62-65.

Liu, J. (1986). "The role of cationic polyacrylamide as a dewatering aid in reed pulps," Tappi 69(2), 86-89.

Liu, X. A., Whiting, P., Pande, H., and Roy, D. N. (2001). "The contribution of different fractions of fines to pulp drainage in mechanical pulps," J. Pulp Paper Sci. 27(4), 139-143.

Luukko, K., and Paulapuro, H. (1999). "Mechanical pulp fines: Effect of particle size and shape," TAPPI J. 82(2), 95-101.

MacDonald, I. F., Chu, C. F., Guillot, P. P., and Ng, K. M. (1991). “A generalized BlakeKozeny equation for multisized spherical particles," AIChE J. 37(10), 1583-1588.

MacGregor, M. A. (1983a). "A description of sheet stratification caused by wet pressing," Tappi J. 66(6), 53-57. 
MacGregor, M. A. (1983b). "Practical effects of sheet stratification caused by wet pressing," Tappi J. 66(7), 65-69.

Maloney, T. E., Johansson, T., and Paulapuro, H. (1998). "Removal of water from the cell wall during drying," Paper Technol. 39(6), 39-47.

Maloney, T. C., Laine, J. E., Paulapuro, H. (1999). "Comments on the measurement of cell wall water," Tappi J. 82(9), 125-127.

Maloney, T. C., Paulapuro, H., and Stenius, P. (1998). "Hydration and swelling of pulp fibers measured with differential scanning calorimetry," Nordic Pulp Paper Res. J. 13(1), 31-36.

Manfield, W. H. (1986). "A review of the economics of water removal," Paper Technol. Ind. 27(7), 290-294.

Mantar, E. M., Genco, J. M., and Co. A. (1995). "Drainage characteristics of pulp slurries under dynamic conditions," J. Pulp Paper Sci. 21(2), J44-J50.

Marton, J. (1980). "The role of surface chemistry in fines - alum interactions," Tappi 63(2), 121-125.

Marton, R., and Robie, J. D. (1969). "Characterization of mechanical pulps by a settling technique," Tappi 52(12), 2400-2406.

Martorana, E., and Kleemann, S. (2006). "Influence of de-foamers and de-aerators on paper properties and process parameters," International Paperworld IPW (11-12), 2223.

Mason, S. G. (1950). "The specific surface of fibers - Its measurement and application," Tappi 33(8), 403-409.

Maunier, C. O., and Ramarao, B. V. (1996). "Effect of flocculation on pulp drainage characteristics," Proc. TAPPI 1996 Engineering Conf., TAPPI Press, Atlanta, 221238.

McDonald, J. D., and Amini, J. (1998). "Predicting the press dewatering of heavyweight grades,” Proc. TAPPI Intl. Eng. Conf., Vol. 2, 563-570.

McGregor, C., and Knight, P. (1996). "Utilizing process chemicals to improve water removal," Paper Technol. 37(8), 31-37.

McNeal, M., and Nanko, H. (2006). "The effect of polymer conformation on microparticle efficiency in drainage and retention," Proc. TAPPI 2006 Papermakers Conf., TAPPI Press, Atlanta.

Meyer, H. (1962). "A filtration theory of compressible fibrous beds formed from dilute suspensions," Tappi 45(4), 296-310.

Miller, D. C. (1998). "Practical aspects of water management," in TAPPI 1998 Wet End Operations Short Course Notes, 235-281.

Mitchell, C., and Johnston, R. (2000). "Pulsating suction during vacuum dewatering and its effect on the rate and extent of water removal," APPITA Annual General Conf., Vol. 2, 443-447.

Miyanishi, T., and Shigeru, M. (1997). "Optimizing flocculation and drainage for microparticle systems by controlling zeta potential," Tappi J. 80(1), 262-270.

Moberg, K. (1985). "Highly filled papers: Obstacles and approaches," Proc. TAPPI 1985 Papermakers Conf., TAPPI Press, Atlanta, 119-121. 
Molina, R., Krkoška, P., and Blažej, A. (1984). "The influence of pitch elements and fibers upon papermaking properties of bagasse pulp," Papir a Celuloza 39(2), V13V16.

Moss, P. A., and Retulainen, E. (1997). "The effect of fines on fiber bonding: Crosssectional dimensions of TMP fibers at potential bonding sites," J. Pulp Paper Sci. 23(8), J382-J388.

Nazhad, M. M., and Paszner, L. (1994). "Fundamentals of strength loss in recycled paper," Tappi J. 77(9), 171-179.

Nelson, R. W. (1964). "Approximate theories of filtration and retention," Tappi 47(12), $752-764$.

Noda, T., Enomae, T., Isogai, A., and Okuda, T. (2005). "The effect of di(oleamidoethyl) ammonium salt addition at the wet end on drainage and sheet properties," Nordic Pulp Paper Res. J. 20(4), 430-435.

Nordén, H., and Kauppinen, P. (1994). "Cake filtration with application to dewatering of pulp,” Nordic Pulp Paper Res. J. 9(4), 208-213.

Norman, B., Sjödin, U., Alm, B., Björklund, K., Nilsson, F., and Pfister, J.-L. (1995). "Effect of localized dwatering on paper formation," 1995 International Paper Physics Conference, 55-59, September.

Onabe, F., Yamazaki, A., Usuda, M., and Kadoya, T. (1983). "Effect of the polyioncomplex formation on the drainage behavior of pulp suspensions: An interpretation of the dual-polymer system," Mokuzai Gakkaishi 29(1), 60-67.

Ormerod, D. L. (1984). "Fines management is a papermaking necessity," Paper Trade J. $168(5), 45-46$.

Paavilainen, L. (1993). "Conformability - flexibility and collapsibility - of sulphate pulp fibers," Paperi Puu 75(9-10), 689-702.

Paradis, M. A., Genco, J. M., Bousfield, D. W., Hassler, J. C., and Wildfong, V. (2002). "Determination of drainage resistance coefficients under known shear rate," Tappi J. $1(8), 12-18$.

Paradis, M. A., Genco, J. M., Bousfield, D. W., Hassler, J. C., and Wildfong, V. (2003). "Measurement of drainage under conditions of known shear rate," J. Pulp Paper Sci. 29(12), 395-400.

Parker, J. D. (1972). The Sheet-Forming Process, a Project of the Fluid Mechanics Committee, TAPPI Press, Atlanta.

Patel, M., and Trivedi, R. (1994). "Variations in strength and bonding properties of fines from filler, fiber, and their aggregates," Tappi J. 77(3), 185-192.

Persson, T., and Österberg, L. (1969). "A laboratory apparatus for pulsed drainage," Svensk Papperstidn. 72(15), 446-452.

Pfau, A., Schrepp, W., and Horn, D. (1999). "Detection of a single molecule adsorption structure of poly(ethylenimine) macromolecules by AFM," Langmuir 15(9), 32193225.

Pires, E. C., Springer, A. M., and Kumar. V. (1989). “A new technique for specific filtration resistance measurement," Tappi J. 72(7), 149-154.

Polverari, M., Allen, L., and Sithole, B. (2001). "Effects of system closure on retention and drainage aid performance in TMP newsprint manufacture. Part 2," Proc. TAPPI Papermakers Conf., TAPPI Press, Atlanta, 13-33. 
Pruden, B. (2005). “The effect of fines on paper properties," Paper Technol. 46(4), 1926.

Pruszynski, P., and Jakubowksi, R. (2002). "Impact of conductivity and cationic demand on drainage of TMP-based newsprint furnish," APPITA Ann. General Conf., 323-331.

Przybysz, K., and Szwarcsztajn, E. (1973). "Effect of crill on pulp freeness," Przeglad Papier 29(4), 105-108.

Rahman, L. (1987). "The mechanism of fines and filler retention in newsprint furnishes," Tappi J. 70(10), 105-112.

Räisänen, K. (1996). "High-vacuum dewatering on a paper machine wire section - A literature review," Paperi Puu 78(3), 113-120.

Räisänen, K., Karrila, S., and Maijala, A. (1996). "Vacuum dewatering optimization with different furnishes," Paperi Puu 78(8), 461-467.

Räisänen, K., Paulapuro, H., and Karrila, S. (1995). "The effects of retention aids, drainage conditions, and pretreatment of slurry on high vacuum dewatering: A laboratory study," Tappi J. 78(4), 140-147.

Ramarao, B. V., and Kumar, P. (1996). "A model for the gravity drainage of papermaking," Nordic Pulp Paper Res. J. 11(2), 86-94.

Ramarao, B. V., Kumar, P., and Tien, C., (1994). "Drainage and fine particle retention in static formers," Proc. TAPPI Engng. Conf., Vol. 2, 783-797.

Rauch, R., and Sangl, R. (2000). "Latest findings on entrained air and dissolved gases in pulp suspensions," Proc. TAPPI 2000 Papermakers Conf., TAPPI Press, Atlanta, 159-175.

Retulainen, E., Moss, P., and Nieminen, K. (1993). "Effects of fines on the properties of fiber networks," in Products of Papermaking, Vol. 2, Trans. $10^{\text {th }}$ Fund. Res. Symp., Oxford, Pira Intl., Leatherhead, UK, 727-769.

Robertson, A. A., and Mason, S. G. (1949). "Specific surface of cellulose fibers by liquid permeability method," Pulp Paper Mag. Can. 50(12), 103-110.

Rojas, O. J., and Hubbe, M. A. (2004). "The dispersion science of papermaking," J. Dispersion Sci. Technol. 25(6), 713-732.

Roschy, A., Fischer, K., and Kleeman, S. (2002). "Comparison of modern wet end methods for the determination of dewatering and retention at a laboratory scale," Wochenbl. Papierfabr. 130(18), 1187-1196.

Sampson, W. W. (1997). "The interdependence of sheet structure and drainage," Paper Technol. 38(8), 45-50.

Sampson, W. W., and Kropholler, H. W. (1995). "Batch-drainage curves for pulp characterization,” Tappi J. 78(12), 145-151.

Scalforotto, R. E., and Tarvin, R. F. (1984). "Efficiency of polymeric additives on drainage and dewatering," Tappi 67(4), 80-84.

Scallan, A. M., and Carles, J. E. (1972). "The correlation of the water retention value with the fiber saturation point," Svensk Papperstidn. 75(7), 699-703.

Scallan, A. M., and Tigerstrom, A. C. (1992). "Swelling and elasticity of the cell walls of pulp fibers," J. Pulp Paper Sci. 18(5), J188-J193.

Scott, W. E. (1986). "Fines management and control in wet-end chemistry," Tappi J. 69(11), 30-34. 
Seo, Y. B., Shin, Y. C., and Jeon, Y. (2000). "Enzymatic and mechanical treatment of chemical pulp," Tappi J. 83(11), 64. (digital document).

Shands, J., and Hardwick, C. (2000), "Dewatering on a high vacuum flat box," Ann. Mtg. - Tech. Sec., Canadian Pulp Paper Assoc., Preprints, Vol. A, A113-A117.

Sherman, L. M., and Keiser, B. A. (2003). "A new microparticle to improve drainage of a NSSC-containing furnish,"

Sikora, M. D., and Stratton, R. A. (1981). "Shear stability of flocculated colloids," Tappi 64(11), 97-101.

Solberg, D., and Wågberg, L. (2002). "On the mechanism of GCC filler retention during dewatering - new techniques and initial findings," J. Pulp Paper Sci. 28(6), 183-188.

Springer, A. M., and Kuchibhotle, S. (1992). "The influence of filler components on specific filtration resistance," Tappi J. 75(4), 187-194.

Springer, A. M., and Pires, E. C. (1988). "The effect of fibrous fines on tissue properties," Tappi J. 71(2), 99-102.

Springer, A. M., Waller, M. H., and Bhatia, O. P. (1989). "Development of a dynamic press simulator," Tappi J. 72(2), 149-153.

Steadman, R., and Luner, P. (1985). "The effects of wet fiber flexibility on sheet apparent density," in Papermaking Raw Materials, V. Punton (ed.), Mechanical Eng. Publ. Ltd., London, Vol. 1, 311-337.

Steenberg, B., Sandgren, B., and Wahren, D. (1960). "Studies on pulp crill," Svensk Papperstidn. 63(12), 395-397.

Stone, J. E., and Scallan, A. M. (1966). "Influence of drying on the pore structures of the cell wall," in Consolidation of the Paper Web; Trans Symp. Cambridge, Sept. 1965, F. Bolam (ed.), Vol. 1, 145-174.

Ström, G., and Kunnas, A. (1991). "The effect of cationic polymers on the water retention value of various pulps," Nordic Pulp Paper Res. J. 6(1), 12-19.

Sullivan, R. R., and Hertel, K. L. (1942). "The permeability method for determining specific surface of fibers and powders," Adv. Colloid Sci., K. O. Kraemer (ed.), Vol. $1,37-80$.

Sutman, F. J. (2000). "Development and validation of an improved drainage testing methodology," Tappi J. 83(4), 69. Digital document.

Swerin, A., Risinger, G., and Ödberg, L. (1996). "Shear strength in papermaking suspensions flocculated by retention aid systems," Nordic Pulp Paper Res. J. 11(1), 30-35.

Swerin, A., Risinger, G., and Ödberg, L. (1997). "Flocculation in suspensions of microcrystalline cellulose by microparticle retention aid systems,” J. Pulp Paper Sci. 23(8), J374-J381.

Swerin, A., and Ödberg, L. (1997). "Some aspects of retention aids," in The Fundamentals of Papermaking Materials, C. F. Baker (ed.), Pira International, Leatherhead, Surrey, UK, Vol. 1, 265-351.

Swerin, A., Ödberg, L., and Lindström, T. (1990). "Deswelling of hardwood kraft pulp fibers by cationic polymers," Nordic Pulp Paper Res. J. 5(4), 188-196.

Szikla, Z. (1986). "Z-directional distribution of fines and filler material in the paper web under wet pressing conditions," Paperi Puu 68(9), 654-664.

Szikla, Z., and Paulapuro, H. (1989). "Changes in Z-direction density distribution of paper in wet pressing," J. Pulp Paper Sci. 15(1), J11-J17. 
Tam Doo, P. A., and Kerekes, R. J. (1982). “The flexibility of wet pulp fibers," Pulp Paper Can. 83(2), T37-T41; 83(9), 9.

Tanaka, H., Luner, P., and Côté, W. (1982). "How retention aids change the distribution of filler in paper," Tappi 65(4), 95-99.

Tanaka, H., Swerin, A., and Ödberg, L. (1993). "Transfer of cationic retention aid from fibers to fine particles and cleavage of polymer chains under wet-end papermaking conditions," Tappi J. 76(5), 157-163.

Thode, E., Bergomi, J. G., and Unson, R. E. (1960). "The application of a centrifugal water-retention test to pulp evaluation," Tappi 43(5), 505-512.

Thode, E. F., and Ingmanson, W. L. (1959). "Factors contributing to the strength of a sheet of paper. I. External specific surface and swollen specific volume," Tappi 42(1), 74-83.

Tiller, F. M., and Cooper, H. R. (1960). "Role of porosity in filtration. IV. Constant pressure filtration," AIChE J. 6(4), 595-601.

Tiller, F. M., and Shirato M. (1964). "Role of porosity in filtration. VI. New definition of filtration resistance," AIChE J. 10(1), 61-67.

Thode, E. F., Bergomi, J. G., Jr., and Unson, R. E. (1960). “The application of a centrifugal water-retention test to pulp evaluation," Tappi 43(5), 505-512.

Unbehend, J. E., Ramarao, B., Faigen, S. M., and Ramaswamy, S. (1989). “Assessment of drainage during papermaking - Z-directional distribution of stock components during sheet formation," Proc. TAPPI Engg. Conf., TAPPI Press, Atlanta, 45-56.

Van de Ven, T. G. M. (1984). "Theoretical aspects of drainage and retention of small particles on the Fourdrinier," Pulp Paper Can. 85(3), T58-T63.

Van de Ven, T. G. M., Abdallah Qasaiheh, M., and Paris, J. (2005). "Fines deposition on pulp fibers and fines flocculation in a turbulent-flow loop," Ind. Eng. Chem. Res. 44(5), 1291-1295.

Wandelt, P., Tarnawski, W. Z., and Perlinska-Sipa, K. (2005). "Possibilities for upgrading OCC pulp by its refining and fines management," Paperi Puu 87(4), 265-269.

Wang, F., and Hubbe, M. A. (2001). "Development and evaluation of an automated streaming potential measurement device," Colloids Surf. A, 194(1-3), 221-232.

Wang, X., Paulapuro, H., and Maloney, T. C. (2005). "Chemical pulp refining for optimum combination of dewatering and tensile strength," Nordic Pulp Paper Res. J. 20(4), 442-447.

Waterhouse, J. F., and Omori, K. (1993). "The effect of recycling on the fines contribution to selected paper properties," in Products of Papermaking, Vol. 2, C. F. Baker, Ed., Pira Int'1., Leatherhead, UK, p. 1261-1292.

Wegner, T. (1987). "The effects of polymeric additive on papermaking," Tappi 70(7), 107-111.

Wei, H., Kumar, P., Ramarao, B. V., and Tien, C. (1996). "Drainage and fine particle retention in a forming incompressible fibrous mat," J. Pulp Paper Sci. 22(11), J446$\mathrm{J} 451$.

Weise, U., Maloney, T., and Paulapuro, H. (1996). "Quantification of water in different states of interaction with wood pulp fibers," Cellulose 3(4), 189-202.

Whitney, R. P., Ingmanson, W. L., and Han, S. T. (1955). "Some aspects of permeation, filtration, and fluidization," Tappi 38(3), 157-166. 
Wildfong, V., Genco, J., Bousfield, D. W., and Hassler, J. (2003). "A twin wire drainage model for various blade configurations," Proc. TAPPI Spring Tech. Conf., 579-590.

Wildfong, V. J., Genco, J. M., Shands, J. A., and Bousfield, D. W. (2000). "Filtration mechanics of sheet forming. Part I: Apparatus for determination of constant-pressure filtration resistance," J. Pulp Paper Sci. 26(7), 250-254.

Wildfong, V. J., Genco, J. M., Shands, J. A., and Bousfield, D. W. (2000). "Filtration mechanics of sheet forming. Part II: Influence of fine material and compression," $J$. Pulp Paper Sci. 26(8), 280-283.

Wood, J. R., Grondin, M., and Karnis, A. (1991). "Characterization of mechanical pulp fines with a small hydrocyclone. Part 1: The principle and nature of the separation," J. Pulp Paper Sci. 17(1), 1-5.

Wood, J. R., and Karnis, A. (1996). "Determination of specific surface area of mechanical pulp fines from turbidity measurements," Paperi Puu 78(4), 181-186.

Woodward, T. W. (1996). "Recycled fiber types, processing history affect pulp behavior during papermaking," Pulp Paper 70(8), 81-83.

Yoon, D.-H., and Park, J.-M. (2005). "Fibers flocculation and physical property changes of paper depending on cationic polymer addition," Palpu Chongi Gisul 37(1), 10-16.

Youn, H. J., and Lee, H.-L. (2002). "An experimental investigation of the effect of pulp types, mechanical treatments and crill contents on fiber network strength," Appita 2000, 71-79.

Zauscher, S. (2000). "Surface and friction forces between cellulose surfaces measured with colloidal probe microscopy," Nordic Pulp Paper Res. J. 15(5), 459-468.

Zeilinger, H. and Klein, M. (1995). "Modern measuring methods for determination of the filler distribution of paper in the Z-direction," Wochenbl. Papierfabr. 123(20), 903910.

Zhang, M., Hubbe, M. A., Venditti, R. A.,. and Heitmann, J. A. (2004). "Effects of sugar addition before drying on the wet-flexibility of redispersed kraft fibers," J. Pulp Paper Sci. 30(1), 29-34.

Zhu, S., Pelton, R. H., and Collven, K. (1995). "Mechanistic modeling of fluid permeation through compressible fiber beds," J. Chem. Eng. Sci. 50(22), 3557-3572.

Zotterman, C., and Wahren, D. (1978). "A technique for simulating production quality of high-speed wet press runs," Paper Trade J. 162(16), 37-38, 64. 